日本線虫学会第16回大会講演要旨

文部科学省 研究交流センター (つくば市) 2008年 9 月17 - 19日

\title{
A bstracts of papers presented at the 16th annual meeting of the Japanese Nematological Society in T sukuba, September 17-19, 2008
}

特別講演

\section{Special lecture}

近藤栄造 (佐賀大農) 大学における線虫学教 育と研究事情 E. Kondo (Saga Univ.) Current status of nematological education and studies at Japanese universities

昨年、“ A griculture, Nematology and the Society of Nematologists”が出版された。本年発刊の “A A A necdotal History of Nematology”には、線虫 研究の歴史と炎の背景が記されている。本年 7 月にオーストラリアで開催された第 5 回国際線 虫学会では、“Education and Training for Future Generation of Nematologists - The pre-sent status and future strategy on the nematological education and training in Africa and A sia -”がシンポジウム課題 として取り上げられた。国内では、ここ数年の 間に、試験研究機関や大学の組織改編がなされ てきた。国内外において、線虫に関する試験研 究と教育の環境は大きく変わりつつある。線虫 に関する研究と教育を精力的に展開するととも に、炎の社会的な意義を再考する時期に入った ようだ。

“寄生虫”という言葉は、社会一般に通用す る。しかし、“線虫”の知名度は低い。線虫学の 本論に入る前に、“線虫とは吅”という序論が 必要になる。科学おける線虫学の位置づけを示 す一つの指標として高校教科書 (生物) の内容 をチェックすると、線形動物、細胞系譜、RNAi、
土壤生物、C . エレガンス、マツ材線虫病、ネコ ブセンチュウなどが取り上げられている。しか し、大学入学者に対する質問“線虫って何?” に対する回答の量と質から判断して、高校教育 において、“線虫の世界”を十分に伝えていると は思えない。このような事情もあるため、線虫 研究の世界には、アマチュアが非常に少ない。 セミプロまたはプロの世界になっている。裙野 が狭い。C．エレガンスを用いた目覚しい基礎研 究がある一方で、農業上重要な植物寄生性線虫 についての研究 (Nematology) には多くの課題 がある。

線虫研究に携わっている仲間内 (線虫学会内) では、線虫研究の意義は自明のこと、検討不要 なことと思えるかも知れないが、弚うではない。 1976年と1977年の日本線虫研究会の小集会では、 「線虫問題と試験研究」について意見交換がなさ れ、多くの解決すべき課題が示されている。光 れから30年以上を経た現在においても、線虫に 関する試験研究の在り方を問い続けることの必 要性は変わらないどころか、大きくなっている。 線虫学会会員が所属している光れ光れの職場等 において、線虫に関する試験研究の意義（重要 性）と面白さを伝えたい。

日本の大学は、人口減少・老齢化、地域社会 の衰退、食料生現場 (農業) の現況などを反映 して、また、平成16年 4 月の国立大学法人化を 契機として、大きく変貌しつつある。高等教育 機関である大学の教育機能の強化、社会的責務 の達成、社会に対する説明責任などを、人員と 経費が減る中で実施しなければならない。大学 
における線虫に関する教育と研究の在り樣と実 績が問われている。なによりも、大学は、次代 を担う学生に希望を語る必要がある。学会大会 では、線虫を中心に据え、大学と社会の関係 (接点) について、現況と課題を紹介したい。

日本線虫学会 (1993年設立) は、満15歳の青 春期にある。日本線虫研究会設立 (1971年) か ら起算すると 37 歳の壮年期である。この機に、 線虫に関する試験研究と教育の今後を展望しな がら、何をすべきかを考えたい。

$$
\text { シンポジウム I }
$$

線虫を巡るIPM研究の現状と展望

\section{Symposium I}

\section{Current status and future prospects of IPM studies of nematodes}

北上 達 (三重農研) ネコブセンチュウの IPM技術と今後の展望 T. Kitagami (Mie Agr. Res. Inst.) Current status and future prospect of IPM technology for root-knot nematode control

ネコブセンチュウは農業生産上、最も重要な 有害線虫のひとつ (グループ) である。ネコブ センチュウをはじめ、有害線虫の防除手段につ いては、他の病害虫の場合と同樣に「化学合成 農薬に過度に依存した防除」への反省などから、 IPM体系を構築する重要性が認識されるように なっている。ここでは、これまでに開発された 多くの防除技術の概要について簡単に触れ、今 後のネコブセンチュウ防除におけるIPMの展望 を考えてみたい。

1 . ネコブセンチュウ防除技術の概要

1 ) 化学的防除

当然のことながら、化学合成農薬はIPMの重 要なアイテムである。土壤くん蒸剂や接触型粒 剂などを線虫密度の高低、他の病害虫の発生状 況、対象作物の栽培状況等に応じて使い分ける
ことが可能である。作付け前の処理が基本であ るが、ホスチアゼート液剂は生育期に処理する ことができ、作期が長い作物の栽培後期におけ る対策として有効である。ただ、安定した高い 防除効果を有するが故に、依存度が高まってい る感は否めない。

2 ) 耕種的防除

対抗植物として、クロタラリア属植物やソル ゴーなどが実用化されている。栽培体系に緑肥 作物が組み込まれている場合は、弚れを対抗植 物に置き換えることで導入できるが、長期間の 固場占有、植物自体の経济性など、普及のネッ クとなる面もある。抵抗性品種はサツマイモで 数多く実用化されている。トマトではほとんど の品種に抵抗性因子が導入されているが、これ を打破する系統が出現している。

3) 物理的防除

太陽熱処理は施設における有効な防除法であ るが、天候等によって効果が不十分となる場合 がある。この改良法として土鋊還元消毒法が開 発され、より短期間・低温域で安定した防除効 果を得ることが可能となった。他に熱水土壌消 毒や蒸気消毒があるが、装置・設備への投資が 必要である。

4 ) 生物的防除

絶対寄生性細菌のパスツーリア菌は野菜類、 サツマイモ、イチジクを対象に実用化されてい る。効果持続性や高い環境耐性を有することか ら「切り札」としての期待が高く、他の防除手 段との併用や処理法の改良等が検討されてきた が、価格、遅効性、効果確認の困難さなどの原 因により、広く普及するには至っていない。線 虫捕捉系状菌のモナクロスポリウム菌はトマ卜、 ミニトマト、タバコを対象に実用化されている が、価格、ハンドリングなどの面から普及は進 んでいない。

2 . ネコブセンチュウ防除におけるIPMの展望 ネコブセンチュウに対しては樣々な防除技術 が研究・実用化されてきたが、現状において線 虫防除の中心的役割を担っているのは、相変わ らず土壤くん蒸剂などの化学合成農薬である。 従来の防除技術は、パスツーリア菌を除き「被 
害が発生するほど高まった線虫密度を低減させ る」ことを主目的としてきた。しかし、IPM体 系を構筑するには「線虫密度が高まる前に増殖 を抑制・管理する」という観点への転換と、そ れを可能とする基幹技術の開発が不可欠であろ う。しかも、关の技術は安価、簡便で安定した 効果を有し、一般に受け入れやすいものでなけ ればならない。越えるべきハードルは高いが、 食糧の安定供給の一翼を担うためにも、今後の 研究の進展を大いに期待したい。

奈良部 孝 (北海道農研) ジャガイモシストセ ンチュウのIPM技術の開発と展望 T. Narabu (Nat. A gr. Res. Ctr. Hokkaido, NA RO) Development and prospect of the integrated management of potato cyst nematode, Globodera rostochiensis in Japan

ジャガイモシストセンチュウ (PCN) は1972 年北海道で初めて発生が確認されて以来、2007 年には道内発生面積約 1 万ha、道外 3 県へと発 生が拡大した。ジャガイモの収量減および種い も栽培可能地域の縮小など被害は深刻である。 現在実施可能な防除手段は、非寄主作物と抵抗 性品種を取り入れた輪作、および感受性品種栽 培時に殺線虫剂 (粒剂) を使用する総合対策で ある。これらを適切に組み合わせることで、根 絶は難しいものの、PCNの密度をゼロに近づけ ることができる。抵抗性品種は国内のどの地域 個体群に対しても抵抗性を示し、密度低減に有 効で、減収もほとんど無い (高密度時に減収す る品種あり) ため (串田ら，2004)、IPMの中核と 位置づけられる。抵抗性品種は用途別・熟期別 に多数が利用可能 (道内の優良指定品種で26種、 2007年度末) であるにもかかわらず、全抵抗性 品種のシェアは $5 \%$ 程度しかない。今後、抵抗 性品種の普及がPCN防除の鍵となる。

将来実施可能な防除手段として、対抗植物お よびふ化促進物質の利用が有望である。ナス科 対抗植物Solanum sisymbriifoliumおよびS. peruvianumは、休閑緑肥として利用することで、国 内でもPCN密度低減効果が確認された（山田ら， 2007)。前者はすでに西欧で実用化され、普及が 進んでいる。今後、利用目的に合致するコス卜
での栽培が可能になれば、日本においても実用 技術となる可能性がある。一方、ふ化促進物質 は、寄主植物の根から分泌され、耐久態のシス 卜から幼虫を一斉にふ化させる作用がある。こ れを人為的に非寄主作物栽培時に土壃処理する と、幼虫が一斉にふ化するものの飭となる作物 根がなく、やがて餓死するため、センチュウ密 度の大幅低減が期待できる。PCN ふ心化促進物質 は単離・同定報告はあるものの ( M u d derら， 1992)、合成物質は未だ入手できない。このため、 PCN 寄主植物であるトマトの水耕栽培時の廃液 や廃材に含まれる心，化促進物質を有効活用する 方法を検討した。光の結果、室内試験および固 場試験においてPCN密度低減効果が確認された。 心.化促進物質の低コス卜大量回収・製剂化技術、 固場への効果的な処理技術など、今後の検討課 題は多いものの、将来のIPMの中核技術として 期待される。

現在のPCN対策では、新規発生圑場をこれ以 上増やさないことが重要課題である。圑場間の ヒトとモノの移動を完全に制限するのは困難な ので、まず、既発生圑場の密度を極力低減し、 伝播リスクを軽減する必要がある。さらに、防 除技術の開発・普及と共に、圑場のPCN モニタ リングを充実させる必要がある。光こで、生産 現場において簡便にPCNの検出と密度推定が可 能な「プラスチックカップ検診法」を開発した。 この手法は、市販の小型蓋付き透明カップに検 診土壤と種いもを入れ、発根を促進することで、 根の表面に黄色シストを出現させ、透明カップ 越しに観察を行う生物検定法である。この手法 を道内PCN発生地域に適用した結果、従来法と 同等以上の精度で土壌からのPCN検出が可能で、 実用的な卵密度推定ができた。この手法は、熟 練や高額機器を必要とせず、生産現場で誰もが 利用可能であることから、普及に向けた取り組 みが進められている。

田辺博司 (株)エス・ディー・エス バイオテッ クつくば研究所 病害虫・バイオグループ) Steinernema属昆虫病原性線虫による害虫防除の 現状と展望 H. T anabe (SDS Biotech K.K. T sukuba 
Research \& Technology Center, Plant Protection Biology Group) Current status and future directions of insect pest control by the steinernematid entomopathogenic nematodes

昆虫病原性線虫（以下天敵線虫とする）は、 世界各国で生物的防除に利用されている有用な 天敵生物の一つである。

一般的に、天敵生物は寄主特異性が高く、生 物農薬としての実用的利用における対象病害虫 種の範囲は余り広くは無い。これに対し、天敵 線虫は、対象とする害虫に対して病原性を持つ 共生細菌を害虫体内で放出・増殖することで殺 虫効果が発現する。光のため、共生細菌が病原 性を有する害虫種に対して、広く実用的防除の 可能性を有している。

欧米において、古くは1930年代から天敵線虫 の生物的防除資材としての利用の可能性が検討 されてきており、現在では、 2 属 7 種以上の天 敵線虫種が製品として流通している。防除対象 もコガネムシ類幼虫、ケラ、ゾウムシ類、チョ ウ目幼虫、キノコバエ類幼虫、ミカンキイロア ザミウマなど、実防除に利用されている対象害 虫種は多岐に及心゙。

更に、最近ヨーロッパでは、有効な防除手段 が少ないコナジラミ類防除に対する天敵線虫の 利用が検討されており、展着剂との併用により 実用的な防除手段として、光の確立が期待され ている。今後も天敵線虫製剂は、生物的防除な らびにIPMの重要なツールの一つとして兴の利 用の範囲を広げていくことになるであろう。

一方、現在日本国内において普及している天 敵線虫製剂は、Steinernema carpocapsae All系統 (商品名 ; バイオセーフ ${ }^{\circledR}$ ) およびSteinernema glaseri sds102系統 (商品名; バイオトピア ${ }^{\circledR}$ ) の 2 種であり、これらの製品も年々谷の適用害虫 の範囲を広げている。

Steinernema carpocapsae製剂は、野菜類ハスモ ンヨトウ、果樹類モモシンクイガ、芝を加害す るシバオサゾウムシ、タマナヤガ、かんしょの ハスモンヨトウ、アリモドキゾウムシ、イモゾ ウムシ、および、花卉類キンケクチブトゾウム シなど、土壤中で加害、或いは生息するステー
ジを対象とした利用だけではなく、いちじくの キボシカミキリ、もも・おうとうのコスカシバ、 なしのヒメボクトウ、オリーブのオリーブアナ アキゾウムシ、および、たらのきのセンノカミ キリなどの枝幹害虫類も適用害虫となっている。 有効成分である天敵線虫自身が加害孔内で宿主 害虫を探索、死亡させることができ、有効な防 除手段が少ない枝幹害虫を対象に利用場面の拡 大が進行している。

Steinernema glaseri製剂は、重要土壌害虫であ るコガネムシ類幼虫に対して特に効果が高いこ とを特徵としており、芝を加害する土猿害虫類 (コガネムシ類幼虫、シバオサゾウムシ、シバツ トガ、スジキリヨトウ、タマナヤガ)、かんしょ のコガネムシ類幼虫に対する適用と共に、化学 農薬の登録剂が少ないブルーベリー、ハスカッ プなどに光の適用場面を広げている。

以上のように、天敵線虫製剂は土壤中や樹幹 内など、化学農薬が到達しにくい環境下で、有 効成分自身が感染対象を探索して効果を発揮す る唯一の「天敵」生物であり、日本国内におい ても、今後、更なる利用場面の拡大に期待した い。

前原紀敏（森林総研東北）マツノザイセンチュ ウの微生物的防除 - 菌類利用の試み N. Maehara (Forestry \& Forest Prod. Res. Inst., T ohoku Res. Ctr.) Fungal control of Bursaphelenchus xylophilus

\section{1 .はじめに}

マツ材線虫病を防除するために現在最も普通 に行われているのは、病原体マツノザイセンチ ユウを媒介するマツノマダラカミキリの成虫を 殺虫剂によって殺す方法 (予防散布) と枯死木 材内のマツノマダラカミキリの幼虫を殺虫剂や 燻蒸剂によって殺す方法 (伐倒駆除) である。 殺虫剂による防除は、効果が高く速い反面、生 態系内の他の生物への悪影響や環境污染を引き 起こす可能性もある。また、燻蒸剂は効果と安 全性は高いが、被害材をシートで密閉する必要 があり手間がかかるとともに、急斜面などでは 適用できないこともある。光こで、演者らは昆 虫病原菌Beauveria bassianaを利用してマツノマ 
ダラカミキリの成虫および幼虫を防除するため の研究を行ってきた。

一方、マツノザイセンチュウに対する予防措 置として、殺線虫剂の樹幹注入がある。予防効 果が高く、環境への悪影響の心配もないが、高 価なため大面積での実施には不適である。また、 線虫の駆除措置に関しては、材内のマツノマダ ラカミキリ幼虫に対して用いる殺虫剂や燻蒸斉 に殺線虫効果もあることが分かっているが、上 記のような問題点がある。光のため、演者らは 菌類を用いてマツノザイセンチュウを防除する ための研究も併せて進めてきたので、本講演で はこちらを中心に紹介する。

2 . 菌類によるマツノザイセンチュウの微生物 的防除

マツノマダラカミキリが保持するマツノザイ センチュウの数は、本病の広がりを決定する重 要な要因の一つである。すなわち、マツノマダ ラカミキリのマツノザイセンチュウ保持数が皆 無かあるいは非常に少ない場合には、マツ類樹 木は枯れない。光のマツノザイセンチュウ保持 数に影響する要因を調べたところ、マツノマダ ラカミキリの蛹室に青変菌がよく繁殖している 場合に、乥こから羽化脱出したマツノマダラカ ミキリが保持するマツノザイセンチュウの数が 多くなることが明らかになった。青変菌は、マ ツノザイセンチュウの増殖と分散型第 3 期幼虫 の出現にとって好適な菌類である。光こで、 樣々な菌類をアカマツ枯死木に接種して青変菌 の繁殖を抑制することで、材内の線虫密度を低 下させ、マツノマダラカミキリが光こから運び 出すマツノザイセンチュウの数を減少させるこ とを試みた。マツノザイセンチュウを直接殺す のではなく、餌をなくすことによって増殖を抑 える、すなわち線虫を「兵糧攻め」にするとい う発想に基づいている。また、線虫寄生菌を接 種してマツノザイセンチュウを直接殺すことで、 材内の線虫密度を低下させることも試みた。光 の結果、T richoderma属菌 (兵糧攻め菌) および Verticillium属菌 (線虫寄生菌) に、マツノマダラ カミキリが保持するマツノザイセンチュウの数 を減少させる効果が見られた。現在は、病原体
マツノザイセンチュウに対する兵糧攻め菌およ び線虫寄生菌と、媒介者マツノマダラカミキリ に対する昆虫病原菌の併用について、さらに研 究を進めている。

Z. A. Siddiqui (Kyoto Univ., A ligarh Muslim Univ.) Biocontrol of plant parasitic nematodes by bacteria and fungi

Bacteria and fungi are most abundant in field soils and some of them have great potential as biocontrol agents of plant parasitic nematodes. Fungi continuously destroy nematodes in virtually all soils because of their constant association with nematodes in the rhizosphere. A large number of fungi are known to trap or prey on nematodes but the most important genera include Paecilomyces, Pochonia, Hirsutella, Nematophthora, Arthrobotrys, Drechmeria, Fusarium and $M$ onacrosporium. Similarly, plant growth promoting rhizobacteria (PGPR) reduce nematode populations by colonizing the root and by imparting beneficial effect on host plant. A large number of PGPR are known to reduce nematode populations and important genera include A zospirillum, A zotobacter, Bacillus, Burkholderia Enterobacter, $\mathrm{K}$ lebsiella and Pseudomonas. Mixture of these biocontrol agents with different colonizing pattern is more useful in controlling nematodes via different mechanisms of disease suppression. Naturally occurring biocontrol results from mixture of biocontrol agents rather from high population of single biocontrol agent. Some of these bacteria and fungi may also be used in integrated nematode management programs. There is an urgent need to develop some easy technologies for formulation and mass production of bacteria and fungi at a commercial scale for field application.

$$
\text { シンポジウム II }
$$

線虫とバイオダイバーシティー 


\section{Symposium II}

\section{Nematodes and their biodiversities}

皆川 望 (九州沖縄農研) 生物多樣性と線虫: 研 究の基本概念、土壤の質と健全性との関わり、 兴の他 N. Minagawa (Nat. A gr. Res. Ctr. Kyushu Okinawa Reg.) Biodiversity and nematodes: research concept, relation to the soil quality and health, etc.

Ogma属、Neolobocriconema属などトゲワセンチ ユウ類はおもに林地に生息し、日本から20種以 上が報告されている。これらトゲワセンチュウ 類は、体の表面に、針状、とげ状、うろこ状な どの突起があり、これが種を識別する重要な特 徵となっている。しかし、計測值には、種によ る大きな違いはない。また、トゲワセンチュウ 類の分布をみると、日本国内では、北海道のみ に分布する種はシベリアやヨーロッパにも分布、 本州や北海道の高山帯から検出される種はシベ リアと北米にも分布、本州・四国・ 九州から検 出される種は朝鮮半島にも分布、沖縄の種の多 くは他地域から検出されない、さらに国外でも、 オーストラリア、ニュージーランドおよび大洋 州には他地域にみられない独特の分類群が分布 するなど、他の植物寄生性線虫の多くが属ある いは種レベルで地球上の同じような気候帯に広 く分布するのと違って、昆虫や脊椎動物など他 の生物とよく似た地理的分布パターンを示す。 これらのことから、計測值に基づいた従来の研 究手法では、形態的特徵の少ない植物寄生性線 虫の種を完全には識別できていない可能性があ るのではないかという疑問が生じる。しかし、 今回は、このような分類学的な内容にはあまり 深入りせずに、線虫をおもな材料に、生物多樣 性について広く考えてみたい。

トゲワセンチュウ類の種の多くは林木や果樹 などの木本を寄主とし、一部はススキ、ダンチ クなどのイネ科の多年生草本に寄生している。 しかし、畑地、水田、人工草地からは検出され ない。このことから、トゲワセンチュウ類は、 林地、果樹園など樹園地、自然草地の指標生物 と言える。一方、日本国内では線虫を対象とし
た研究事例は多くないが、国内外のさまざまな ところで線虫を含む生物多樣性の調査研究が行 われている。このような研究を行うことで光こ に生息する生物のリストができあがる。ところ で、このような研究は、調査してリストを作り 現状を把握するという以外の研究目的は何か、 研究の結果は何に使うのか。また、本シンポジ ウムで話題提供される、海洋線虫の多樣性、ネ コブセンチュウなど寄生性の異なる植物寄生性 線虫のレース判別、標高に伴う線虫相の変化な ど線虫の地理的分布、線虫の形態的な多樣性に 関する光れ光れの研究はつながりをもつものな のか。さらに、自活性線虫を含めた線虫の多樣 性に関する研究と、土壤の質 (soil quality) とか 土壤の健全性 (soil health) の評価とどのように 関連するのか。あるいは、個々の研究者が行う 生物多樣性の研究と、国際的な生物多樣性条約 やこの条約に基づく国別の生物多樣性国家戦略 といった国内外の政治を巻き込んだ大きな動き との関連をどのように理解すればよいのか。改 めて生物多樣性と言われる範疇 (研究分野) を 考えてみると、分かっているようでよく分から ないことが多い。

シンポジウム「線虫とバイオディバーシティ 一」の最初に行う私の講演では、トゲワセンチ ユウ類の分類を話の頭に、線虫の多樣性と土壤 の質・健全性の評価を話の締めにして、弚のあ いだに、生物多樣性研究の意味・目的、自然環 境の保全と農業など土地利用と管理、生物多樣 性条約や生物多樣性国家戦略产の他の話題を挟 んで話をしたい。これは、線虫の多樣性研究は このような方法で調査しデータを解析すればこ のように使えるとか、線虫の生物多樣性に関す る研究の目的はこうあるべきだといった結論を 提示するような話ではなくて、分かったようで よく分からない生物多樣性と光れを取り巻くも ろもろのことを概観しながら、線虫と生物多樣 性について会員の皆さんとともに考えていくき っかけになればという、問題提起をねらいとし た話である。

白山 義久 (京大フィールド研) 海産自活性 
線形動物の生物多樣性研究の現状 - 全海洋生物 のセンサスとNaGISA プロジェクトの展開 $Y$. Shirayama (Field Science Education and Research Center, Kyoto University) Review of the Current Status on the Biodiversity Research of Free-living Marine Nematodes - Development of Census of Marine Life and NaGISA (Natural Geography In Shore A rea) Projects

2000年から2010年までの予定で、現在世界中 に生息する海洋生物の多樣性、分布、個体数を 評価し解明するために企画された科学研究プロ グラムである海洋生物のセンサス (Census of Marine Life, CoML, http://www.coml.org/) プロジェ クトが展開されている。世界で75力国2000名以 上が参加する巨大プロジェクトであり、下記に あげる主要な4本の柱から構成されている。過去 を調べるHMAP ( History of Marine Animal Population)、現在を調べる14のフィールドプロ ジェクト、未来を予測するFMAP (Future of Marine A nimal Population)、これらの研究成果を格 納するデータベース (OBIS: Ocean Biogeography Information System)。

14あるフィールドプロジェクトのうち、沿岸 域の生物を対象としているのが、NaGISA (Natural Geography In Shore A rea) プロジェクト である。演者が研究主任を務め、瀬戶臨海実験 所を本部として北米・南米・東南アジアなどを 中心に、すでに50力国以上が参加している国際 プロジェクトでもある。

このフィールドプロジェクトは、沿岸生物の 多樣性の地理的パターンを地球規模で明らかす ることを目指しており、すべての参加者が統一 された方法で海洋生物を採集・分析し、光のデ 一夕を持ち寄って地域間比較をすることを目指 している。最終年度の2010年までに、全世界に わたるデータを集積し、今世紀初頭での世界の 沿岸生態系の全体像を明らかにすると共に、今 後心配される地球環境の变化に伴う海洋生態系 の変化をモニターするための基礎資料を提供し ようとしている。

このプロジェクトの採用している生物の採集 方法は、体長 $1 \mathrm{~mm}$ 以下のいわゆるメイオベント
スもカバーしており、線形動物も各地点で10万 個体以上が採集されている。現在のところこれ らの試料は、採集された地域の研究者による研 究成果を待っている状態であるが、解析は必ず しも順調に進んでいるとはいえない。光の主要 な原因は人材不足である。NaGISAでは、この問 題に対処すべく、教育にも力を入れており、分 類トレーニングの国際ワークショップを2008年 の春に開催した。今後新たに海産自由生活型線 虫類に興味を持った若手の研究者により、世界 中で解析を待っている線虫標本の研究が進展し、 沿岸の線形動物の多樣性が明らかになっていく ことを期待している。

海洋生物全体で、多樣性を記載するデータベ ースが構築されてきているが、この点でも残念 ながら線形動物に関するデータは極めて希薄で ある。今後も地道な記載論文の継続的な出版を 続けることがしばらくの間は必要であろう。

W. A hmad and M. Baniyamuddin. (A ligarh Mulsim Univ.). Nematode diversity along altitudinal gradients in Eastern Himalayas, India

The Himalayas represent one of the youngest mountain ranges in the world, separating Indian subcontinent from Tibetan Plateau, forming an arc, 2,400 kms long from Indus valley in the west to the Brahamputra river valley in the east. It varies in width from $400 \mathrm{~km}$ in the western Kasmir-Xinjiang region to $150 \mathrm{~km}$ in eastern Tibet-A runachal Pradesh region. A runachal Pradesh is the 25th state of India, in the eastern Himalayan zone situated between $26^{\circ}$ $28^{\prime}$ and $29^{\circ} 30^{\prime}$ north latitude and $97^{\circ} 30^{\prime}$ and $97^{\circ}$ $30^{\prime}$ east latitude, and is one of the twelve hot spots of biodiversity in the world. It stretches from the snow capped mountains in the north to the plains of Brahamputra valley in the south. The entire territory forms a complex hill system of varying elevation ranging from $50 \mathrm{msl}$ in the foothills gradually ascending to about 7,000 msl. The natural forest region of A runachal Pradesh is rich in humus and organic constituents, harboring a variety of soil invertebrates including numerous interesting nematode species. 
Because of wide range of altitudinal variations, the vegetation of this region can be classified into five forest types, the tropical forest, subtropical forest, pine forest, temperate forest and alpine forest. The undisturbed primary forest representing a mature ecosystem provides high range of nematode diversity and is most suitable to study their community structure. A comparative study was conducted to know the taxonomic diversity, trophic diversity, functional diversity and dominance of soil inhabiting nematodes at three altitudinal range, viz., 400-500 msl (Itanagar - tropical forest), 1,200-1,300 msl (T irap - subtropical forest) and 3,000-3,500 msl (T awang - temperate forest). Diversity index, Maturity Index, Enrichment Index, Structure Index and Channel Index were calculated to compare the diversity and trophic relationships in three regions/three forest types. The results indicated an increase in nematode diversity with increase in altitude from Itanagar (400-500 msl), a tropical forest to Tirap (1,200-1,300 msl), a subtropical forest, but further increase in altitude at T awan (3,000-4,000 msl), a temperate forest, the diversity decreased. In terms of taxonomic diversity, the order Dorylaimida constituted the major share in all the three regions both in terms of generic diversity as well as abundance. A mong trophic groups, although predators dominated in the number of genera in all the three regions, the fungal feeders were most abundant in Itanagar and Tirap whereas predators were most abundant in Tawang. In Itanagar, the genus A xonchium was eudominant while Helicotylenchus, Iotonchus, Eudorylaimus and Dorylaimoides constituted the dominant genera among sixty genera recorded. In Tirap, out of eighty five genera recorded, no genus was eudominant, while the dominant genera were Axonchium, Eucephalobus, Helicotylenchus and Eudorylaimus. In Tawang, Axonchium, Helicotylenchus, Eudorylaimus, Dorylaimellus and Ironus, were dominant genera with no eudominant genus. In all the three regions the genera A xonchium, Helicotylenchus, and Eudorylaimus were dominant. The values of $\mathrm{MI}, \mathrm{SI}$ and $\mathrm{EI}$ in all the three regions indicated a stable ecosystem, however, the values were higher in temperate forest compared to tropical and subtropical, rather a gradual increase with altitude.

V. V. Yushin (Inst. Mar. Biol. FEB RAS) and A. Y. Ryss (Zool. Inst. RAS) Sperm structure and development in Bursaphelenchus mucronatus (Nematoda: Parasitaphelenchidae)

The nematode spermatozoa represent an aberrant type of male gametes; they are characterized by the absence of an axoneme and acrosome. The basic type of nematode spermatozoon is an amoeboid bipolar cell with anterior pseudopod and posterior main cell body (MCB) which includes condensed nucleus, mitochondria and so called membranous organelles' (MO), unique aberrant organelles characteristic of developing and mature sperm of many nematodes studied. Usually MO look like large vesicles with dense content and system of internal finger-like projections of outer membrane. The MO appear as a part of the complexes with paracrystalline fibrous bodies (FB) composed from densely packed parallel filaments consisting of the unique cytoskeleton protein MSP. The complexes of FB and MO '( FBMO complexes' ) during late stages of spermatogenesis dissociate into separate $F B$ and $M O$. A fter sperm activation inside female gonoduct $\mathrm{MO}$ join to plasmalemma of sperm MCB and release their content into the uterus lumen. Then empty MO, looking like membranous sacs continuous with the sperm plasmalemma, retain as a constant feature of mature sperm. The sperm activation is accompanied also by transformation of FB into the MSP based cytoskeleton of a newly formed pseudopod. Five major patterns of nematode spermatogenesis may be defined. Each pattern is distinguished clearly by special developmental pathways of MO and FB. The patterns and taxa in question are the following: i) MO and FB develop as M O-FB complexes in most Rhabditida and in some other Chromadorea; ii) MO and FB occur but their development is asynchronous and independent in 
many Enoplida; iii) MO do not appear, only FB are developed in Tylenchoidea within Rhabditida, as well as in some Chromadorida and Desmodorida; iv) FB do not appear, only MO are developed in some Enoplida, M ononchida, M ermithida, T richurida, Dioctophymida; v) aberrant organelles are absent at all the stages of sperm development in Dorylaimida, some M ononchida, Chromadorida, Desmodorida and Rhabditida. The analysis of nematode male gametes may be demonstrated by example of the aphelenchoidid Bursaphelenchus mucronatus (Parasitaphelenchidae) which spermatogenesis was studied recently. The male reproductive system of $B$. mucronatus comprises only one testis which is a simple epithelial tube filled with germ cells. The distal tip of the testis contains spermatogonia followed by spermatocytes, spermatids and immature sperm. The spermatocytes are synthetically active to produce large amount of vesicles filled with dense matter. The vesicles grow quickly and transform into bipartite organelles each consisting of a vesicle which flattened processes envelope a paracrystalline body. These cytoplasmic components may be easily identified as the M O-FB complexes well known for nematode sperm. The complexes increase and finally dissociate into separate large F B and MO in spermatids. Immature spermatozoa contain nucleus, mitochondria and separate aberrant organelles, FB and M O. Mature spermatozoa from the female gonoduct lack FB but have their derivative as a small pseudopod. MO are empty peripheral vesicles joined to plasmalemma of the sperm MCB. All the features found in the the B. mucronatus spermatogenous cells are well coincide with the typical ' rhabditid' type (pattern' i' ) of sperm development and structure.

岩堀英晶 (九沖農研) DNA シークエンスからみ たネコブセンチュウ類とミナミネグサレセンチ ユウのバイオディバーシティー H. Iwahori (Nat. Agr. Res. Ctr. Kyushu Okinawa) Biodiversity of M eloidogynespp. and Pratylenchus coffeae as revealed with DNA sequences
今やDNA シークエンスは身近な技術となり、 多くの生物の膨大な塩基配列がインターネット サイトに登録され、我々は光れらをいつでも自 由に閲覧できる。線虫に関しても、DNA シーク エンスはこれまで形態に頼っていた種同定のた めの強力なツールとなり、また、他国の線虫の 塩基配列との比較も容易にできるようになった。 本講演ではバイオディバーシティーをDNA シー クェンスの変異 (ジェネティックディバーシテ ィー) の観点から捉え、これまで演者が行って きたネコブセンチュウ類とミナミネグサレセン チュウのDNA シークェンス結果を中心に、これ らの分類や分化との関わりについて考えてみた い。

サツマイモネコブセンチュウの個体群間変 異 : 本種には樣々なサツマイモ品種に対して寄 生性の異なるレース (SP 1 〜 9) の存在が明ら かとなっている。これらは地理的分布に特徵が あることが判明しているが、DNAの変異との関 連性は不明であった。光こで、レース識別マー カー探索のため、ミトコンドリア(mt)DNA/COII16SrDNA 領域の塩基配列決定を行った。九州沖 縄地域の代表的なレースSP $1 ， 2 ， 4 ， 6 の$ 各 4 個体群を調査した結果、これらの間の変異は レースや採取された地理的位置とは関係が見ら れなかった。

ネコブセンチュウ類の種内および種間変異 : 前述のmtDNA 領域の塩基配列を 5 種類のネコブ センチュウで調べたところ、種内変異の大きさ は種によって異なっていた。Mh注) は種内変異 が大きく3.02\% (4 個体群)、次いでM mが1.16\% ( 7 個体群)、Miが0.83 (17個体群)、Ma (hon) が0.25 ( 3 個体群)、Ma (oki) が0.17\% (5個体群)、 Mjが0.08 ( 3 個体群) の順であった。Mh以外の 種は種内変異がきわめて少なく、また、種間の 比較でも変異は同種と言ってもよいほど少なか つた。近年、Mi，Ma，Mj（恐らくはMmも）は共 通の杂隹種起源の種で、比較的最近生じた種であ ることが示唆されており、このことがmtDNAの 塩基配列に種内および種間変異が少ない理由と 考えられた。一方でまれに欠失を持った個体群 が見つかり、母集団と混棲していた。このよう 
な欠失の発生機構は不明であるが、光れ光れ世 界に広く分布するMaのhonは欠失を持たずokiが 欠失を持った系統であることから、欠失個体群 の存在は種分化と何らかのつながりがあるのか も知れない。

ミナミネグサレセンチュウの種内型 : 本種に は寄生性とリボソーム(r)DNA /IT S1-2領域の制限 酵素断片長多型 (RFLP) パターンが異なり、不 完全な生殖隔離を示す 3 つ系統 $(A ， B ， C$ 型) が知られている。これらのrDNA/D2-D3領域の塩 基配列を調べたところ、A型（９個体群）には 2 塩基のみ異なる 2 タイプの配列が見られたが、 $A$ 型とは23〜29塩基異なるB型 ( 6 個体群) と C 型 ( 4 個体群) に型内変異は見られなかった。B 型とC型の違いは 4 塩基のみであり、互いに近縁 であった。これらを既報の塩基配列と比較した ところ、A 型は基準産地インドネシアの個体群 と同一であったが、B型とC型は日本独自の系統 であった。近年、九州沖縄地域ではRFLPパター ンが異なる新たな型が見出されており、本種の 種分化樣式の解明のための新たな知見が加わる ことが期待される。

注 ) Mi：サツマイモネコブセンチュウ、 Ma(hon):アレナリアネコブセンチュウ本州型、 Ma(oki): アレナリアネコブセンチュウ沖縄型、 M m:ナンヨウネコブセンチュウ、Mj:ジャワネコ ブセンチュウ、Mh:キタネコブセンチュウ

\section{一般講演}

\section{Papers}

丸山洋介・池野 嵩 (北大) - 植原健人 (北農 研) ・山口淳二・後藤デレック (北大) 植物と 植物寄生センチュウの相互作用 Y.Maruyama, T. Ikeno (Hokkaido Univ.), T. Uehara (NARC Hokkaido), J. Y amaguchi and D. B. Goto (Hokkaido Univ.) Interactions between plants and plant parasitic nematodes

センチュウは生態系で多くの部分を占める生
物の一種であり、世界の農作物被害の $5 \%$ はセ ンチュウによる被害である。センチュウに対し て抵抗性を示す作物の作出、またトマトにおい てサリチル酸経路に関係するセンチュウ抵抗性 遺伝子Miなどが明かとなっている。しかし、セ ンチュウに対する植物の防御応答に関する詳細 な機構は以前不明のままである。

植物のセンチュウに対する防御応答機構の詳 細を解明するために、私たちは、モデル植物で あるシロイヌナズナ、マイクロトマトを用いて、 センチュウ感染時における植物遺伝子の発現解 析を行った。具体的には、病原体応答に関与す るサリチル酸経路・エチレン/ジャスモン酸経 路に関係する遺伝子群、傷害応答に関係する遺 伝子群の発現解析を実施した。感染後 3 日、3 日のPR遺伝子の発現には非感染植物と比較して 差異がみられた。詳細な解析により、植物はセ ンチュウの感染に対して防御応答していること が示された。

浦上敦子 - 德田進一 - 村上健二 - 佐藤文生 - 相 澤証子・國久美由紀・東尾久雄 (野菜茶研) キャベツ連作圃場における堆肥連用がキタネグ サレセンチュウ密度に与える影響 A. Uragami， S. Tokuda, K. Murakami, F. Sato, S. A izawa, M. Kunihisa, and H. Higashio (Natl. Inst. Veg. Tea Sci.) Effects of composted manure on Pratylenchus penetrans populations in continuous cropping fields of cabbage.

牧草の均一栽培が行われていたキタネグサレ センチュウ (P. penetrans) 污染圃場 (火山性壤 土）に、1区0.25 a $(5 \mathrm{~m} \times 5 \mathrm{~m})$ の試験区画を 3 ブロックの乱塊法で設置し、おがくず牛糞堆肥、 戻し堆肥 (牛糞)、発酵彩糞、乾燥豚引うんの4種 類の堆肥をキャベツ定植1か月前に施用した。施 用量は化成肥料区の窒素含量 $(25 \mathrm{~kg} / 10 \mathrm{a})$ を基 準に設定した。肥効の劣るおがくず牛粪堆肥は、 窒素含量に基づき、1 倍量、2 倍量、3 倍量お

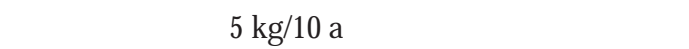
を設けた。対照区として化成肥料区、無肥料区、 慣行施肥区を設けた。キャベツ作付けは春夏作 および秋冬作の年 2 回とし、2002年秋作から作 
付けを開始し、作付け前毎に土壤中の全炭素量 をNCアナライザーで調査した。線虫密度は、2 作目〜 6 作目 (2003年春夏作〜2007年春夏作) にわたってキャベツ定植時と収穫直後にベルマ ン法で調査した。光の結果、P. penetrans数は、 定植時から収穫時にかけての増加と収穫後の減 少のパターンを繰り返した。Tukeyの多重検定の 結果、特にキタネグサレセンチュウ密度の増加 した収穫後に、多くの処理間で有意差が認めら れた。また、P. penetrans数 (自然対数値) およ び自活性線虫数 (自然対数値) と、土壤中の全 炭素量および投入した有機物量との間の相関関 係を検討した結果、光れ光れの間に有意な相関 関係が多く認められた。

上杉謙太・岩堀英晶・立石 靖 (九沖農研) 住友克彦 (花き研) クマモトネグサレセンチ ユウのキクにおける増殖と被害の品種間差異 K. Uesugi, H. Iwahori, Y. T ateishi (Nat. Agr. Res. Ctr. Kyushu Okinawa) and K. Sumitomo (Nat. Inst. Flori. Sci.) Reproduction and pathogenicity of Pratylenchus kumamotoensis on chrysanthemum cultivars

クマモトネグサレセンチュウ (以下線虫) の キクにおける増殖と被害の品種間差異をポット 条件下において検討した。増殖性の調査には輪 ギク、小ギク、スプレーギク、古典ギクの各品 種群から計16品種を供試し、線虫300頭を接種し た後に 3 か月間栽培した。試験終了時のPf/Piは 15品種において281-812となり、いずれの品種群 においても著しい増殖か認められた。一方、「つ くば1号」(スプレーギク ) の増殖率はPf $/ \mathrm{Pi}=22$ となり、他の品種の1/10以下と低かった。被害 の調査には、増殖性の低い「つくば1号」、中程 度の「沖の白波」、高い「神馬」を用い、初期密 度約200頭/20 g土猿 (ベルマン法) に調整したポ ットに定植して3か月間栽培した。終了時の根 重は 3 品種とも対照の $60 \%$ 以下と線虫加害の影 響が大きかった。しかし、草丈は「神馬」にお いて15\%低下したものの、「つくば1号」、「沖の 白波」では終了時まで差が見られなかった。こ れら 2 品種では地上部乾重や下位葉の枯れ上が りへの影響も比較的小さかった。以上の結果か
ら、キク圑場の線虫密度はほとんどの品種にお いて速やかに上昇するが、被害の顕在化には栽 培品種の影響が大きいものと考えられた。

星野 滋 (広島総研農技セ) - 山内 稔 - 井上 博喜 (近中四農研) ・富樫一巴 (東大農) 鉄 コーティング処理がイネシンガレセンチュウの 生存と増殖に及ぼす影響 S. Hoshino (A gricultural. T ech. Res. Ctr. Hiroshima Pref. Tech. Res. Inst.), M. Y amauchi, I. Inoue (Nat. A gr. Res. Ctr. Kinki Chugoku Shikoku) and K. Togashi (Tokyo Univ.) Influence of iron coating of rice seeds on survival and reproduction of $A$ phelenchoides besseyi

イネ種子の表面で鉄粉を発熱させて酸化する ことにより、鉄を種子に固着させて (鉄コーテ イング処理) 水田に直播する栽培法が開発され ている。光こで、鉄コーティング処理がイネシ ンガレセンチュウの生存と増殖に及ぼす影響を 明らかにするために、イネシンガレセンチュウ 感染種子に鉄コーティングまたはカルパーコー ティング処理を行い、炎の効果を検討した。種 子を水に浸漬して生存幼虫数を調べたところ、 鉄またはカルパーをコーティングした種子内の 線虫生存率は、無処理の弚れよりも有意に低く なった。種子を本田に播種し、ほたるいもちの 発生茎率と発生株率を調査したところ、鉄コー ティング処理では、カルパーコーティング処理 よりも弚れらの值は有意に低かった。収穫期の 種子当たりの線虫数は鉄コーティング処理とカ ルパーコーティング処理の間に有意な差はなか つた。

以上の結果、鉄コーティング処理が種子内の 線虫数を減少させ、ほたるいもち発生を抑制す ることが明らかになった。現在、イネ種子の鉄 コーティング処理を行う工程内での線虫の死亡 について調査中である。

山下一夫 (青森農林総研畑園試) イモグサレ センチュウの行動に及ぼす数種植物抽出液およ び化学物質の影響 K. Yamashita (A omori Pref. A gr. For. Res. Ctr., Field Crops \& Hort. Exp. Stn.) The effects of extracts from several plant species and 
chemicals on behaviors of Ditylenchus destructor

ニンニクの生産阻害要因の一つであるイモグ サレセンチュウは防除困難なため、現在も発生 は拡大している。青森県内 8 町村13固場で発生 する線虫についてIT S 領域を増幅する数種のプラ イマーを用いたPCR法を行い、一部について塩 基配列を決定した結果、既報のイモグサレセン チュウと高い相同性が見られ、遺伝子レベルで 改めて同定された。本試験では、植物汁液や薬 剂等が本線虫の行動に及ぼす影響について、寒 天内拡散法を応用して調査した。素寒天中では 活発に集合と離散を繰り返した後、30日前後で ほとんどが活動を休止した。ニンニク品種福地 ホワイトの汁液と他のニンニク品種を含む数種 植物汁液を対峙して選好性を比較すると、すべ てのニンニク品種およびタマネギに対する選好 性はネギやリーキより強かった。また、ジャガ イモに対する選好性はニンニクよりも強かった。 ニンニク部位別でみると、根に対する選好性は 葉および鱗片より強かった。さらに、ジャガイ モ汁液に殺線虫剂の成分を添加して調査したと ころ、カズサホスは誘引を阻害せず、ホスチア ゼートは誘引阻害した。一方、数種の薬剂や 酸・アルカリ溶液中での耐性を調査した結果、 多くの薬剂に対して耐性が認められた。また、 ネギ萎调病菌の培養菌叢では菌系を吸汁して生 存したが、ニンニク春腐病菌コロニー中では数 日で死滅した。

相場 聡 (中央農研) ダイズシストセンチュ ウの寄生性判別のための接種条件の検討 S. Aiba (Nat. A gr. Res. Ctr.) Conditions for cyst nematode inoculation for host status evaluation of soybean cultivars

国内の線虫抵抗性ダイズ品種に対応したダイ ズシストセンチュウのレース検定法を確立する ため、国産抵抗性品種と感受性品種への寄生性 の違いを明確に判断できる接種条件について検 討を行った。今回は線虫の接種頭数およひ増殖 期間について試験したので報告する。

$24^{\circ} \mathrm{C}$ の工気象器内で線虫感受性品種「エン レイ」と抵抗性品種「トヨコマチ」を $9 \mathrm{~cm}$ ポリ
ポットで栽培し、埼玉個体群を1鉢あたり500〜 5,000 頭まで頭数を変えて卵幼虫懸濁液で接種 し、70 日後にポット内のシストの増殖率の違い を調査した。また、同樣にエンレイとトヨコマ チに埼玉個体群及び俱知安個体群の線虫を产れ ぞれ2,000 頭接種し、接種 4 週間後から 1 週間ご とに10 週間後までシスト数を計数して品種間で の寄生程度の違いを調査した。

エンレイでは接種頭数が多いほどシストの数 も増加したが、トヨコマチでは3,000 卵以上では 増殖率が低下し、高密度接種の方が寄生性の違 いが明確になる傾向があった。また、増殖期間 では、埼玉個体群はエンレイ、トヨコマチとも 7 週目まではシスト数が増加したが、光れ以降 はあまり増殖が認められず、また、4〜 5 週で の寄生程度の差が大きかった。俱知安個体群は 7 週目まではあまり増殖が認められず、8週目 以降にシスト数が増加した。各週での寄生程度 の明確な品種間差異はなかった。

後藤圭太・佐藤恵利華・豊田剛己 (東京農工大 学BASE ) 土壤締固めとリアルタイムPCRを介し た新規のダイズシストセンチュウ検出法の開発 K. Goto, E. Soto and K. Toyoda (T okyo Univ. of A gri. $\&$ Tech.) A novel detection method for the soybean cyst nematode Heterodera glycines using soil compaction and real-timePCR

ダイズシストセンチュウ $(\mathrm{SCN})$ やジャガイ モシストセンチュウなど、シストセンチュウに よる污染の程度を判別する際には、管分け法や 二層遠心浮遊法によるシストの分離が不可欠で あるが、これらの手法は顕微鏡下での煩杂隹な作 業を伴い、かつ多大な時間を要する。光こで、 土壤の締固めとリアルタイムPCRを用いた、従 来法に比へ簡易かつ迅速な手法の開発を試みた。 土壤締固めという操作は、供試土壤を圧密する ことで土堙中に存在するすべての線虫やシスト を破壊し、土壌中にこれらのDNA を溶出させる ことを目的として行った。異なった卵密度の $\operatorname{SCN}$ を含む土埣 $(10 ， 25 ， 50 ， 250 ， 500 ， 1,000$ ， $1,500 ， 3,000$ 個/生土20g) を人工的に作成し、特 注の締固め機（大起理化工業株式会社）を用い 
て締固め、その後の土壤0.25 gからDNA を抽出し た。得られたDNA を鋳型としてリアルタイム PCRを実施したところ、SCNの卵密度とCt値との 間に有意な負の相関関係が認められた $\left(r^{2}=0.8615 、 P<0.001\right) 。 ま た$ 新規手法における $\mathrm{SCN}$ の検出限界は約 0.2 シスト/乾土100 g ( 1 シス 卜につき300卵と仮定) であり、3 シスト/乾土 $100 \mathrm{~g}$ というSCNの要防除基準 (相場，2001)よ りも低い密度であった。本手法により、顕微鏡 下でのシストや卵の計数作業を解消することが 可能となった。

奈良部 孝・植原健人・伊藤賢治 (北農研) プラスチックカップ検診法を用いた土猿からの ジャガイモシストセンチュウの定量的検出精度 の検証 T. Narabu, T. Uehara and K. Itou (Nat. A gr. Res. Ctr. Hokkaido, NARO) Detection accuracy of a method using potato tubers grown in closed plastic containers for quantitative determination of Globodera rostochiensis in soil

土猿中のジャガイモシストセンチュウ (PCN) 污染程度を簡便に判別する手法として、小型の 蓋付き透明プラスチックカップに小粒種いもと 検診土壤を入れて暗黑下で培養し、カップ外側 から根へのシスト形成を観察する方法 (以下カ ップ法) を提案した (昨年度本大会)。本報告で は、2地域 2 か年のべ272固場を対象にカップ法 の検診精度を検証した。1 圑場あたり約 $2 \mathrm{~kg} の$ 土壌サンプルを用い、従来法のふるるい分けによ る卵密度 (/g乾土、50 g× 2 反復平均) とカップ 法による観察シスト数 (/カップ、乾土33 g× 3 反復平均) の比較の結果、両者には各地域・年 とも相関関係か認められた (06年 $: r=0.93,0.89$ 、 07 年 $: r=0.90,0.90 ; P<0.001)$ 。近似直線の傾き は06年と07年で若干の差異が認められたが、同 一年では地域間の差異はなかった。同100卵以上 の高密度サンプルでは形成シス卜数は頭打ちと なり、直線関係から外れた。従来法またはカッ プ法の一方のみでPCNが検出されたサンプルは ともに18点 $(6.6 \%)$ で、同 3 卵未満の低密度か つ古くからの発生戋場に限られた。従来法のみ でPCNが検出されたサンプル残土に感受性ジャ
ガイモを栽培したところ、約40\% でシスト形成 が認められなかった。従来法は活性の無い卵を 計数している可能性がある。以上、カップ法は 従来法と同等以上の精度で、土壤中のPCNの発 生および污染程度を簡便に判別できる方法と考 えられる。

大林隆司 (都農総研) - 櫻井文隆 - 吉村聡志 (都中央普セ) - 高木章雄 (都農林水産部) - 伊 藤 綾 (都島しょ農林水産総合セ三宅) - 竹内 浩二(都農総研) エダマメのダイズシストセ ンチュウに対するダゾメット粉粒剂の効果 T Ohbayashi (T okyo Metro. A gr. For. Res. Ctr.), F. Sakurai, S. Y oshimura (T okyo M etro. Chuo Agr. Imp. A dv. Ctr.), A. Takagi (T okyo M etro. Gov. Dep. A gr.), A. Itou (Tokyo Metro. Is. A gr. For. Fish Res. Ctr. Miyakejima Is.) and K. Takeuchi (T okyo Metro. Agr. For. Res. Ctr.) Effects of Dazomet on soybean cyst nematodes infesting green soybean

都内では江東地域や多摩地域を中心に、直売 向けのエダマメの栽培面積が増加しつつあるが、 江東地域の一部で10年程前からダイズシストセ ンチュウ (以下、本種) による被害か顕在化し、 対策に苦慮している。現在、エダマメ栽培で本 種に使用可能な薬剂は限られているため、今後 の登録拡大の予備試験として、エダマメの苗立 枯病と一年生雑草に登録があり、他の作物で線 虫類に登録のあるダゾメット粉粒斉の本種に対 する効果を調査した。2008年 2 月に葛飾区の露 地圑場にダゾメット粉粒剂を $30 \mathrm{~kg} / 10$ a処理し、 対照薬剂としてD-D剂を20 L/10 a処理した。4 月 にエダマメ( 萊音’)を播種し、7 月に収穫調 査を実施した。午の結果、栽培終了時の土壤中 の卵数は薬剂処理直後と比較して無処理では大 きく増加したが、薬斉処理区では大幅に減少し、 かつD-D剂とダゾメット粉粒剂はほぼ同じ卵数で あった。なお、収穫物の黄化程度・シスト寄生 程度・葉色・草丈・株重・莢数・萊重のいずれ も無処理区よりも良好であり、かつD-D剂と同等 の効果か認められた。

串田篤彦 (北農研) アカクローバ栽培による 
ダイズシストセンチュウ密度低減の実用性 A . Kushida (Nat. Agr. Ctr. Hokkaido) Practical effects of red clover cultivation on soybean cyst nematode density

アカクローバの栽培は、ダイズシストセンチ ユウ密度の低減化に効果があることが知られ、 本線虫対策の一つとして農業現場で徐々に広ま りつつある。光こで技術の普及を促進するため、 実際の作付け体系においてアカクローバによる 線虫密度低減効果を詳細に評価した。調査した 作付け体系は、アカクローバを秋まき小麦の間 作緑肥として導入し、小麦の起生期に播種し、 10月上旬に鋤込み、翌年は残存効果を得るため に非寄主作物を栽培し、翌々年にダイズを栽培 する体系とした。

間作当年のクローバ播種時から鋤込み時まで の線虫密度低下率は平均 $77 \%$ であり、対照 (ア カクローバ非間作、平均 $47 \%$ ）と有意な差が認 められた（深さ約 $10 \mathrm{~cm}$ )。しかし、作土層の下 層 $(14-24 \mathrm{~cm})$ での線虫密度低下率はやや低く、 処理 - 無処理間の差も有意ではなかった。さら に、クローバ栽培区、非栽培区共に秋から翌春 の調査時までに約40\%の密度低下が認められ、 この低下により光れまでに得られた密度低下率 の差が縮まることが分かった。この結果、2 年 後の大豆播種時にはクローバ栽培 - 非栽培区間 で線虫密度にほとんど差がなくなり、クローバ 導入の効果が認められなくなることが明らかに なった。これらのことから、アカクローバの利 用は、ダイズシストセンチュウ密度低減化技術 として実用性はないと考えられた。

東岱孝司 (北海道立上川農試) 北海道におけ る新たな寄生性を示すダイズシストセンチュウ 個体群の出現 T. Todai (Hokkaido Prefect. Kamikawa Agric. Exp. Stn) Occurrence of a new parasitic population of soybean cyst nematode (Heterodera glycines) in Hokkaido, Japan

2005〜2007年に北海道上川地方のダイズおよ びアズキ栽培固場におけるダイズシストセンチ ユウの発生実態を調査したところ、79固場中42 直場で本線虫の発生が認められた。このうち30
固場について土壤を採取し、Golden et. al. (1970) の方法に準じてレース検定を行った。すなわち、 採取した土壤を72穴セルトレイに充填し、判別 品種 5 品種およびダイズシストセンチュウ抵抗 性の異なる国産品種 3 品種を播種して、インキ ユベーター内 $\left(25^{\circ} \mathrm{C} 、 \mathrm{RH} 90 \%\right.$ 、24時間日長 $)$ で 6 〜 12週間栽培後、根部に表出した雌性虫ある いはシストを計数し、判定に供した。关の結果、 14個体群がレース 1、15個体群がレース 3 と判 定され、レース 3 と判定された個体群のうち、 13個体群が「下田不知」由来のレース 3 抵抗性 品種「トヨコマチ」に寄生性を示し、レース 1 なども含めると「下田不知」由来の抵抗性品種 に寄生性を示す個体群の割合は90\%を超え「下 田不知」由来の抵抗性の限界が推察された。30 個体群のうち 1 個体群は「PI84751」由来のレー ス1抵抗性品種「スズヒメ」に対して、感受性 品種「Lee」の寄生数の35～88\% 寄生し明らかな 寄生が認められた。これまで、北海道において、 「スズヒメ」に寄生する個体群の報告はなく、新 たな寄生性を示すダイズシストセンチュウ個体 群の出現が確認された。なお、本個体群のレー スは未確定なため今後継続して検定を行う。

福澤晃夫 ·石田広志 - 山本省吾 - 奥村宗平 (東 海大生物理工) ・奈良部 孝 (北農研) ジャ ガイモシストセンチュウの孵化共力因子 A . Fukuzwa, H. Ishida, S. Y amamoto, S. Okumura (T okai Univ.) and T. Narabu. (Nat. A gr. Res. Ctr. Hokkaido) Identification of the hatching synergists for potato cyst nematode

ジャガイモシストセンチュウ (PCN) の孵化 促進物質の単離を前回 (京都) 報告した。孵化 促進物質は水溶性が高く、活性値は $10^{-4} \sim^{-5} \mathrm{~g} / \mathrm{ml}$ の濃度であった。孵化活性物質本体がどこにあ るかを決めるためにトマト根を含む培養土全体 を水-イソプロピルアルコールで抽出した。この 物を酢酸エチルと水で分配分離を行い、水層を 濃縮して粗原料とした。これをポリスチレン系 樹脂HP-20を用いてクロマト分離を行ったところ 水のみで溶出する分画 (Fr1) が大量に得られた。 次いでイソプロピルアルコールの濃度を 10 
(Fr2)，20(Fr3)，30 (Fr4)，50\% (Fr5)まで順次 増加させ分画を得た。共力因子を測定する生物 検定としてジャガイモ根を封入した場合Fr1では 10-6g/mlの濃度で活性を示した。共力因子として の効果が約100倍であり他のFr2〜5は活性を示さ ずこの分画のみか顕著な活性 (64\%) を示した。

ジャガイモ根 (卜マト生体) から発生してい る共力因子の同定のために、デシケーターの上 蓋としてボルト穴付きのステンレス板を作成し 关れらを封入した。活性炭ステンレスカラム 2

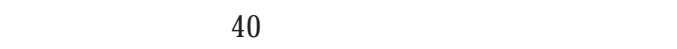
に付したところ 4 分にメタンのピークか現れた。 しかしながら大気中のメタン濃度が1.78 ppmとほ ぼ同等であったことからメタンが共力因子では ないことが判明した。 $110^{\circ} \mathrm{C}$ (9 分)、 $80^{\circ} \mathrm{C}(26$ 分) にエチレンの吸収が現れることから共力因 子はエチレンの可能性が高い。

百田洋二 (農研機構本部) - 藏之内利和 - 高田 明子・中村善行・熊谷 亨 (作物研) スイカ によるキタネコブセンチュウ密度の抑制 Y . Momota (NA RO), T. Kuranouchi, A. T akada, Y. Nakamura and T. Kumagai (NICS) Watermelon cropping reduces population density of the northern rootknot nematode, M eloidogyne hapla

サツマイモネコブセンチュウ (MI) 抵抗性検 定で使用している線虫固場にキタネコブセンチ ユウ $(\mathrm{MH})$ が混発しているため、輪作等により MIを高密度に維持しつつMHを抑制したい。しか し、MHの寄主範囲はきわめて広く、非寄主はイ ネ科以外ではごく僅かしか知られていない。今 回、上記目的のための導入作物としてスイカを 検討した。園芸培土と蒸気消毒畑土壤を等量混 合した無線虫土2,600 gl $\mathrm{MH}$ 二期幼虫2,500頭を含 む線虫土200 gをよく混合してプラスチック鉢に 充_し、スイカ、ホウセンカ、サツマイモを植付 け、温室で栽培した。4 か月後にフロキシンB染 色による卵のう (根こぶ）指数とベルマン法に よる幼虫密度の調査を行った。兴の結果、卵の う指数は光れ光れ0.0、58.3、22.9であった。スイ カから幼虫はほとんど分離されず、分離されて も消耗しきっていた。初期密度に対する増殖率
は、光れ光れ0.009、9.4、3.4であつた（参考供試 ラッカセイ : 15.7)。また、上記線虫圃場におい てサツマイモとスイカの栽培後のM H 密度を作物 間で比較するため、7 月30日に株間20 cmで交互 に植付けて110日間栽培し、根辺土を採取・冷蔵 し、翌年光れにラッカセイをポット栽培した。 兴の結果、スイカ後の卵のう数はサツマイモ後 に比べ明らかに少なかった。以上から、スイカ はMHの非寄主として間違いなく、光の栽培によ りMH密度を大きく抑制できるものと考えられ る。

島袋由乃・田場 聡・安次富 厚 ·諸見里善一 (琉大農) アワユキセンダングサを活用した数 種処理法によるサツマイモネコブセンチュウの 防除 Y. Shimabukuro, S. Taba, A. A jitomi and Z. Moromizato (Ryukyu Univ.) Control of the southern root-knot nematode by several types of treatments using Bidens pilosa L. var radiata Scherff.

沖縄県に生息する29種の未利用植物 (野草) か ら得られた煮沸抽出液を用いてサツマイモネコ ブセンチュウ (以後、ネコブセンチュウ) に対 する抗線虫作用を評価した結果、アワユキセン ダングサ (B. pillosa L. var. radiata) が最も高い活 性を有することが明らかとなった。光こで本研 究ではアワユキセンダングサを利用した効果的 処理法および沖縄の代表的な 3 種土壤 (国頭マ ージ、島尻マージおよびジャーガル) における ネコブセンチュウの防除効果について検討を行 った。in vitroにおいて植物抽出液吸着担体 (以 後、吸着担体) の選抜を行ったところ、パーラ イトで最も高い致死効果が認められた。光こで トマトを用いてポット試験を行った結果、吸着 担体処理区間では原液を吸着させたパーライト を 3 およひ $5 \mathrm{~g}$ 株元処理した場合、根こぶ形成が 最も抑制された。アワユキセンダングサの植物 体破砕物を土壌混和した場合では、根こぶ形成 や線虫密度に対する抑制効果は認められなかっ た。また本植物抽出液をトマ卜地上部に散布し た場合もネコブセンチュウ抑制効果はみられな かった。さらに性質の異なる 3 種土壌を用いて 抽出液の潅注処理を行った結果では、いずれの 
土壤においても顕著な根こぶ形成抑制および線 虫密度抑制効果か認められた。

高良綾乃・小長光義紀・永松ゆきこ (パネフリ 工業(株) ·田場 聡 (琉大農) アワユキセンダ ングサを原料とするネコブセンチュウ防除資材 の開発 A. T akara, Y. Konagamitsu, Y. Nagamatsu (Panefri Industrial Co., Ltd.) and S. T aba (Ryukyu Univ.) Development of materials for root-knot nematode control using Bidens pilosa L. var radiata Scherff extracts

沖縄県に自生する帰化植物であるアワユキセ ンダングサは、元来薬用植物として食用も可能 でありながら、光の旺盛な繁殖力から主要害草 としても知られている。近年、弚の抽出成分が サツマイモネコブセンチュウ 2 期幼虫に対して 高い抗線虫作用を有することが報告されている (T aba et al., 2008)。乥こで本研究では本植物の抽 出液を原料としたネコブセンチュウ防除資材の 開発を行った。光の結果、アワユキセンダング サ1 kgより約40 gの水可溶画分が得られ、光の15 〜150倍希釈溶液が高い殺線虫活性を示した。ま た产の際、アワユキセンダングサ原料の乾燥温 度や時間、さらに抽出時間や温度、液比などの 各種前処理条件の違いによる活性低下はほとん ど認められなかったことから、線虫防除に寄与 する主な有効成分は化学的に高い安定性を有し ていることが示唆された。さらに採取地あるい は生育環境の異なるアワユキセンダングサより 得られた抽出液の殺線虫活性について比較した 結果、ほとんど差は認められなかった。すなわ ち沖縄地域におけるアワユキセンダングサの豊 富なバイオマスを最大限に活用することで、環 境低負荷型の新規線虫防除資材を誘導可能であ ることが示唆された。本研究は科学技術振興機 構 (JST)「産学共同シーズイノベーション化事 業 (顕在化ステージ)」の一環として行ったもの である。

Z. Khan (Dept. Agr. Biotech. Seoul Natl. Univ.) Plant grow th-promoting rhizobacterium, Paenibacillus polymyxa suppresses disease complex caused by root- knot nematode and Fusarium wilt fungus

Paenibacillus polymyxa is a plant growth-promoting rhizobacterium, and used for the biological control of plant diseases. Paenibacillus polymyxa strains collected from rotten ginseng roots were tested for their inhibitory activities and biological control potential for the management of disease complex caused by $M$ eloidogyne incognita and F usarium oxysporum f. sp. lycopersici on tomato. In in vitro experiments, eleven strains of P. polymyxa showed antifungal and nematicidal activities against $F$. oxysporum f. sp. lycopersici and $M$. incognita, respectively. A mong those, P. polymyxa GBR-158; GBR-462 and GBR-508 had the strongest inhibitory activities against both the pathogens, and had also inhibited nematode egg hatch completely. These three most effective strains used in pot experiments; have suppressed the development of disease complex and increased plant growth. The control effect on wilt severity and root galling was $90-98 \%$ and $64-88 \%$, respectively, compared to untreated control. The bacterial treatment inhibited giant cell formation as no or a few small giant cells were observed in plants treated with bacterial suspension.

岩堀英晶 (九沖農研) - 市瀬克也 (国際農研熱 帯島嶼) - Nguyen Thi Ngoc Truc - Le Quoc Dien (ベトナム南部果樹研究所) ベトナム南部のグ アバより初検出されたM eloidogyne mayaguensisに ついて H. Iwahori (Nat. A gr. Res. Ctr. Kyushu Okinawa), K. Ichinose (IIRCA S Tropical A gr. Res. Front), N. T. N. Truc and L. Q. Dien (SOFRI) First record of the root not nematode, M eloidogyne mayaguensis, from southern Vietnam

ベトナム南部ではカンキツグリーニング病対 策の1つとしてグアバ混植効果の実証試験をす すめている。ところが、これら戛場に植えられ たグアバに、葉の褐変、退緑、生長阻害、さら には枯死が見られた。根部を調査したところ、 はげしい根こぶ症状が見られ、ネコブセンチュ ウの寄生が確認された。グアバ根に寄生した雌 成虫1頭を用いてミトコンドリアCOII-16S rDNA 
領域の塩基配列を決定し、既報の種との比較を 行ったところ、M eloidogyne mayaguensis (syn. M. enterolobii）とほぼ一致したことより、ベトナム 南部のグアバを加害するネコブセンチュウを本 種と同定した。本種は中南米、アフリカ、ヨー ロッパの光れ光れ一部、中国 (海南島)、USA (フロリダ) に分布することが知られているが、 ベトナムでは初検出である。簡易DNA 同定法と しては、上記領域のPCR産物（約700 bp）を制限 酵素Alul，Dral，Sspl，Vsplで切断した時のRFLP パターンで確認する方法が有用であり、現地圃 場 2 力所の土壌より分離された 2 期幼虫光れ光 れ10頭ずつ、および1株に寄生した 9頭の雌成虫 を本法により調査したところ、すべて， mayaguensisと識別された。なお混発は見られな かった。

関本茂行 - 酒井啓充 ・佐藤 雅 (横浜植防) 杉並区虫系の森公園のクワから分離されたスギ ナミネコブセンチュウおよび光の他の植物寄生 性線虫 S. Sekimoto, H. Sakai and M. Sato (Yokohama Plant Protec. Stn.) M eloidogyne suginamiensis and other plant parasitic nematode species found in roots and rhizosphere soil of mulberries in “ Sanshi no mori” park in Suginami ward, Tokyo

演者らはネコブセンチュウ類の同定識別手法 について調査を実施しているところであるが、 兴の調査に供するために東京都杉並区虫系の森 公園においてスギナミネコブセンチュウ (以下、 スギナミ) トポタイプの採取を試みる機会を得 た。Toida and Yaegashi (1984) によって記載さ れた本種は、模式産地である蚕系の森公園を含 む 2 力所からの発見記録しかなく、非常に狭い 分布域を持つという点で大変興味深い種である。 今回、演者らが槑系の森公園敷地内においてク ワの根および根辺土猿を採取した結果、スギナ ミが検出された。あわせて根辺土壌から系状線 虫の分離を行ったところ、H elicotylenchus属、 Longidorus属、M eloidogyne属、Paratylenchus属、 Pratylenchus属、Xiphinema属、Criconematidae科な ど、光の他の植物寄生性線虫も検出された。桑 園における植物寄生性線虫については全国的な
調査が行われ、20属32種以上が報告されている (樋田ら，1978; 樋田，1984)。今回の調査結果 は、上記報告における桑園線虫相とよく合致し た。本発表では、蝅系の森公園内におけるスギ ナミの発見状況および根辺土壤から検出された 兴の他の植物寄生性線虫の種類について報告す る。

丸山亮太・小倉信夫 (明大農) - 大胡聖嗣 (ヤ シマ産業) ・菊地泰正 (森林総研) 日本産ヨ モギツブセンチュウについて R. M aruyama, N. Ogura (M eiji Univ.), K. Daigo (Y ashimasangyo) and T. Kikuchi (FFPRI) Subanguina moxae in Japan

筑波山でヨモギの葉にゴールを形成する線虫 を採集した。光こで、平田 (1990) により松本 市安曇一帯および大月市雁力腹摺山で発見され、 ヨモギツブセンチュウとして同定・報告されて いるものと形態およびrDNAのITS領域の塩基配 列を比較した。光の結果、形態計測值について は、雌成虫でb值、V值および口針長、雄成虫で 体長およびb值は各地域間で有意差がなかった。 また、国内の線虫の塩基配列は99\%以上一致し、 筑波山の線虫の当該配列はロシア連邦沿海地方 のヨモギッブセンチュウ (GenBank: Accession No. AF 396314) と完全に一致した。従って、今 回採集した筑波山の線虫はヨモギツブセンチ ユウSubanguina moxae (Yokoo and Choi,1968) Brzeski, 1981と同定した。また、日本産ヨモギツ ブセンチュウrDNAのITS領域のPCR-RFLPでは、 松本市梓川上野において採集した線虫は他の地 域のものとバンドパターンが若干異なっていた。 筑波山のヨモギツブセンチュウの走査型電子顕 微鏡による形態観察も行ったのであわせて報告 する。

嶋田大輔 - 柁原宏 - 馬渡駿介 (北大院理) 北海道における海産自活性線虫の分類学的研究 D. Shimada, H. Kajihara, S. Mawatari (Hokkaido Univ.) T axonomic study of free-living marine nematodes in Hokkaido

線虫の既知種は約 2 万種であり、光のうち半 分が海産自活性種とされる。しかし、日本沿岸 
における海産自活性線虫の分類学的研究は不足 しており、これまでに71種が記載されているに 過ぎない。演者らは、日本沿岸の海産自活性線 虫の多樣性を解明する一助とすべく、2006年か ら2007年にかけて北海道各地の海岸で採集を行 い、光学顕微鏡および走査型電子顕微鏡を用い て形態に基づく種同定を行った。钅の結果、日 本初記録の 7 属を含む15科21属にわたって約 4,000個体の標本が得られ、少なくとも40種の形 態種が含まれることが明らかになった。これら のうちの一部は種名まで同定されたが、光の多 くが日本初記録種であった。また、Epacanthion sp.、Enoplolaimus sp. Oncholaimus sp.1の 3 種は 未記載種であったため、新種記載の準備を進め ている。

本研究によって、北海道に生息する海産自活 性線虫の多樣性の高さの一端が示された。本講 演ではこれまでに得られた結果について紹介す る。

M. Olia (Shahrekord Univ.), W. A hmad (Aligarh Muslim Univ.), M. A raki, N. Minaka (Nat. Inst. A groEnv. Sci.), H. Oba (Nat. Inst. Livest. Grassl. Sci.) and H. Okada (Nat. Inst. A gro-Env. Sci.) Description of Actus salvadoricus Baqri and Jairajpuri, 1974 (Monochida: Mylonchulidae) from Japan with a comment on the phylogenetic position of the genus Actus based on 185 rDNA sequences

A ctus salvadoricus Baqri and Jairajpuri, 1974 collected from subtropical forest in the northern part of Okinawa Island, Japan is redescribed and its phylogenetic position elucidated based on 185 rDNA sequence. Actus salvadoricus is characterized by having buccal cavity with a moderately developed dorsal tooth, vertical subventral plates with a single row of denticles arranged as 3:3 or 3:4 or 2:4 on two plates, distinct excretory pore, elongate-conoid ventrally arcuate tail with tandem caudal glands and terminal spinneret. rDNA sequences (18S and ITS1/2) of this species characterized and based on the nearly complete $18 \mathrm{~S}$ rDNA sequence data, phylogenetic trees using parsimony and maximum likelihood algorithms with the known and new mononchs sequences and Bathyodontus mirus as an outgroup were constructed in PAUP. The results show that the genus Actus forms a sister group with the species of the genus $M$ ylonchulus in the suborder Mononchina, showing the validity of its taxonomic group. This is the first report of the genus Actus Baqri and Jairajpuri, 1974 from A sia.

新屋良治・竹内祐子・植田充美・二井一禎 (京 大院農) マツノザイセンチュウ表面タンパク 質の性質 R. Shinya, Y. T akeuchi, M. U eda and K. Futai (Grad. Sch. A gric. Kyoto Univ.) Characters of surface coat proteins of the pine wood nematode, Bursaphelenchus xylophilus

多くの線虫は光の表皮上に、糖鎖に富む表面 タンパク質 (SCP) を提示していることが知られ ており、この分子が寄主 - 寄生線虫間相互作用 における樣々な重要な役割を担っていると考え られている。発表者らは昨年度の本学会大会に て、樣々な種類の蛍光標識植物レクチンとマツ ノザイセンチュウ (ザイセンチュウ) 表面との 結合樣式を観察することにより、ザイセンチュ ウSCPはステージ間、系統間で性質に違いがある ことを報告した(新屋ら，2007)。本研究では、ザ イセンチュウSCPに関する更なる詳細な情報を得 るために、各ステージ別にザイセンチュウSCPを 採集し、SDS-PA GE 、レクチンブロット法を用い てSCPの性質を精査した。攵の結果、SCPの分子 量および糖鎖修飾樣式と、ステージ特異的な分 子を特定した。これらの結果からザイセンチュ ウSCPでは、これまで他種の線虫においても数多 く報告のある糖鎖の変化だけでなく、タンパク 質自体の変化も生じることが明らかとなった。 また、レクチンブロット解析により得られた結 果から、ザイセンチュウ表面のレクチン結合部 位は何らかの物質により阻害されていることが 示唆された。

真宮靖治 マツノマダラカミキリ成虫のマツノ ザイセンチュウ誘引ー $\mathrm{CO} 2$ 関与の検証 $Y$. Mamiya $A$ ttraction of the pinewood nematode to the 
Japanese pine sawyer adult and $\mathrm{CO}_{2}$

マツノザイセンチュウ (以下、線虫) は $\mathrm{CO}_{2}$ に 誘引されることが、マツノマダラカミキリ (以 下、マダラ) 成虫への乗り移りにかかわる要因 として報告されている。しかしながら、これま での報告には十分な検証が欠けている。本研究 ではマダラ成虫による線虫誘引と、 $\mathrm{CO}_{2}$ 関与の有 無を検証するため、新たな手法のもとで害験を 行った。T型コネクションチュウブ $(5 \mathrm{~cm} \times 3$ 、 内径 $5 \mathrm{~mm}$ ) を用いて、1 \%寒天中における線虫 の動態を追った。人工飼育によるマダラ成虫あ るいは光の死亡虫体を入れた注射筒 $(12 \mathrm{ml})$ を 一端のチュウブに装着し、他端はフリーの注射 筒装着による対照とした。中央のチュウブに線 虫を接種して、12時間、24時間、48時間後にお ける各チュウブ内の線虫を計数した。10 ml管瓶 内の水中で重曹とクエン酸を混合して $\mathrm{CO}_{2}$ を発生 させた。管瓶は一端のチュウブに装着した。他 端のチュウブに水を入れた管瓶を装着して対照 とした。線虫接種後の時間経過とともに、線虫 接種、 $\mathrm{CO}_{2}$ 発生、対照光れのチュウブ内にお ける線虫数を計測した。チュウブ内の線虫はマ ダラ成虫および死亡虫体、 $\mathrm{CO}_{2}$ へ正の反応を示し て移動した。同樣な方法で、線虫が $\mathbf{-}$-ピネン、 $\beta$-ピネン、クロマツ枝組織に対しても正の反応 を示すことを明らかにした。実験結果から、マ ダラ成虫に対する反応には $\mathrm{CO}_{2}$ 関与しているこ とが推測できた。また、死亡虫体に対する反応 から $\mathrm{CO}_{2}$ 以外の要因の関与も示唆された。本研究 は、また線虫とマツ類との相互関係を解析する うえで有効な一手法を示した。

真田陽平 ·藤本岳人 · Hagus T arno ·二井一禎 (京都大農) Steinernema属線虫 2 種を用いた力 シノナガキクイムシの防除法の検討 Y. Sanada, T. Fujimoto, H. Tarno, and K. Futai (Kyoto Univ.) Possibility to control Platypus quercivorus by using Steinernema spp.

近年、西日本各地でブナ科樹木萎调枯死被 害が発生している。本病は病原菌 (Raffaelea quercivora) を保持したカシノナガキクイムシ (Platypus quercivorus、カシナガ) が材内に侵入
することによって発生する。防除方法として、 カシナガの材内への侵入を防ぐ方法、材内から の脱出を妨げる方法など多数開発されてきたが、 いずれも十分な成果を得られていない。乥こで 本研究では、昆虫病原性線虫であるSteinernema 属線虫 2 種のカシナガに対する感染率を測定す ることで、新たな生物防除資材としての可能性 を検討した。1％寒天培地が入った滅菌済みシ ヤーレにカシナガのオスもしくはメスを 1 頭入 れ、同時に50から1,000頭まで10段階の頭数に調 整したS. glaseriもしくはS. carpocapsaeを培地上に 接種した。10日後にカシナガ虫体への感染率を 比較した結果、S. carpocapsaeに比べてS. glaseriの ほうが高い感染率を示した。これは、2 種の宿 主探索能の違いが感染率に影響を及ぼしたため と考えられる。また、S. carpocapsae、S. glaseriと もに線虫頭数の増加に比例してカシナガに対す る感染率は増加した。以上より、S. carpocapsae よりもS. glaseriのほうがカシナガの生物防除資材 として有望であり、施工時の接種頭数を調節す ることでより高い防除効果を得られることが示 唆された。

吉田睦浩 (中央農研) - 大野和朗 (宮崎大学) 日本産昆虫病原性線虫 2 種の施設果菜類栽培環 境における生残能力. M. Y oshida (Nat. A gr. Res. Ctr.) and K. Ohno (Univ. Miyazaki) Survival of the Japanese isolate of an entomopathogenic nematode Steinernema litorale in fruit vegetable greenhouses 前回の大会において、Steinernema litorale (SI) の殺虫活性発現温度と滅菌土中での生残能力に ついて報告した。本報告では本種を中心に、 $25^{\circ} \mathrm{C}$ 以上で高い殺虫活性を示すS. abbasi (Sa) お よび天敵線虫製剂として市販されているS. carpocapsae $(S C)$ を比較対象として、果菜類栽培施 設で行なっている散布試験の途中経過を報告す る。1 ) 中央農研内ハウス : トマ卜を裁植した $1 \mathrm{~m}^{2}$ の方形区に、2007年 6 月にSI、Sa、Scを50万 頭接種した。同年12月に採取した土猿でハスモ ンヨトウの死亡率を調べた。乥の結果SIおよび Sa接種土壤で感染が確認された。両種接種区は 放置し、翌年 4 月に新たにSIを50万頭接種した 
区を設置した。 5 月と 7 月にハスモンヨトウ老 齢幼虫10頭/区放飼し、網かごで囲い込み、光 の死亡率を調査した。5 月放飼では、アリによ る捕食のためヨトウの回収はできなかったが、 7 月放飼では昨年設置した区も含めてSa接種区 で感染が観察された。2) 宮崎県清武町：ハス モンヨトウが常発しているナス -キュウリ栽培 農家の施設において、SIの散布を行った。試験 農家では、10月から翌 2 月にキュウリ、3 月か ら 7 月にナスの栽培が行われ、年間を通じてハ スモンヨトウの発生が見られる。特に、ナス栽 培期間中に発生するハスモンヨトウ老齢幼虫を 防除することを目的として、散布したSIの生残 能力を調査している。2007年11月に5 万頭また は 1 万頭を株元に施用し、翌年 2 月末に採取し た土壤に10頭のハスモンヨトウを放飼し、光の 死亡率を調査した結果、1 万頭区で39～44％、 5 万頭区で54〜 67\%であった。

長谷川浩一・山内春奈・清水彰一・藤吉弘宣 $\cdot$ 堤内 要・三輪錠司 (中部大院) 線虫バイオ センサーを用いたGST 発現誘導物質のスクリー ニングと生物に与える効能評価 K. Hasegawa, H. Yamauchi, S. Shimizu, H. Fujiyoshi, K. T sutsumiuchi, and J. Miwa (Grad. School Chubu Univ.) Nematode biosensors to discover substances effective for life extension and good health

グルタチオンS-トランスフェラーゼ (GST) な どの解毒酵素は、樣々な外因性・内因性ストレ スによる細胞や組織、DNAの損傷を防御する。 生物体内にあらかじめ解毒酵素を誘導しておく ことで、このようなストレスや毒を効果的に排 除することができ、弚の結果、老化や樣々な病 気を予防することができると考えられる。光こ で、私たちはGST 解毒酵素遺伝子と蛍光タンパ ク遺伝子の融合遺伝子を染色体内に組み込んだ 線虫バイオセンサーを用いて、老化や病気の予 防に有益な化学物質の探索・評価法を確立する ことを目指している。今回、線虫1頭からの蛍光 でもGST 発現変化を数值化できる方法を開発し、 ワサビやからしなどに含まれるシニグリンの誘 導体であるアリルイソチオシアネートに応用し

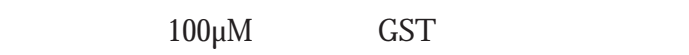
とがわかった。一方、個体レベルでの影響は、 $1 \mathrm{mM}$ 以下の濃度では見られなかったものの、2 $\mathrm{mM}$ 以上では寿命の減少がはっきり観察された。

長谷川浩一・近藤有希菜・三輪錠司 (中部大院) GST 発現経路と光の発現制御機構の遺伝学的解 析 K. Hasegawa, Y. Kondo and J. M iwa (Grad. School Chubu Univ.) Genetic dissection of GST expression pathway and its regulatory mechanism

環境污染物質や食品危害物質、残留農薬など 生体外から摂取される毒物、あるいは生体内で 代謝副産物として発生する活性酸素種などのス トレスは、樣々な病気や老化を引き起こす原因 と考えられている。これら毒物を解毒する酵素 のひとつであるGlutathione S-transferase (GST) は、還元型グルタチオン (GSH) と種々の毒物 との抱合反応を触媒する働きをもち、バクテリ アからヒトに至るまで共通に存在する生体防衛 システムの重要な構成要素である。GST発現経 路と制御メカニズムを解明するため、gst遺伝子 にgfpレポーター遺伝子を組み込んだ線虫をEMS (Ethylmethane sulfonate) で処理し、毒物がなく ても恒常的にGSTを発現する突然変異体を独立 に18ライン分離した。光のうち17ラインは劣性 変異であり、幼虫期から全身で発現するもの、 成虫になったのち咽頭および体壁が光るものに 分けられた。残り 1 ラインは優性変異で、幼虫 期から全身で発現した。幼虫期から全身でGST 発現がみられる劣性変異のうち、7ラインは同 じ遺伝子に起因していることがわかった。さら に従来法およびSNPマッピングにより、連鎖群 I のほぼ中央300kbp以内に关の位置を絞りこむ ことができた。

N. Karim (FFPRI), H. Okada (Nat. Inst. A gro-Env. Sci.) and T. Kikuchi (FFPRI) A nalysis of expressed sequence tags (EST S) of the fungivorous nematode A phelenchus avenae

The fungivorous ability and anhydrobiotic survival capability of $A$. avenae have potentially increased its importance over the other free living soil 
nematodes. In this study, we presented the generation, analysis and annotation of over 5,000 expressed sequence tags (EST s) from a mixed-stage $A$. avenae CDNA library. Clustering of 5,073 high-quality EST s resulted in a set of 2,700 non-redundant sequences comprising 695 contigs and 2,005 singletons. A set of genes with significant homology to the genes encoding plant or fungal cell wall degrading enzymes were identified. With $\mathrm{A}$. avenae cluster sequences, we also provided the functional classification using Gene Ontology (GO) hierarchy and comparative analyses with Caenorhabditis elegans and other protein databases.

藤本岳人 (京大院農) - 長谷川周一 ( 北大院 農) ‘ 乙部和紀・水久保隆之 (中央農研) 土 壤中の水移動と生死がサツマイモネコブセンチ ユウの移動特性におよぼす影響 T . F ujimoto (Kyoto Univ.), S. Hasegawa (Hokkaido Univ.), K. Otobe and T. Mizukubo (Nat. Agr. Res. Ctr) Effects of nematode life and water flow on mobility in soil of the root-knot nematode, M eloidogyne incognita, as revealed by column experiments

サツマイモネコブセンチュウ 2 期幼虫 (Mi) を供試線虫として、土畩水の浸透に伴う線虫の 移動が产の生死や土猿の違いによってどのよう に変化するか測定した。断面積 $3 \mathrm{~cm}^{2}$ 、長さ 11 $\mathrm{cm}$ の円形アクリルカラムに $0.8 \mathrm{~mm}$ ガラスビーズ、 砂もしくは黑ボク土を均一な密度で充填した。 飽和後、カラム端から $5.5 \mathrm{~cm}$ の位置に生きたMiも

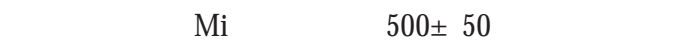
た。浸透量はカラムの中心から流出口までの $5.5 \mathrm{~cm}$ に含まれる水をすべて置換できるだけの量 (PV) で調節し、一定の流速 $\left(36 \mathrm{~cm} \mathrm{~h}^{-1}\right)$ で2.0 PV 浸透させ、0.1 PVごとにカラム外に排出され たMiを計数した。生きた線虫はいずれの土壤に おいても2.0 PV浸透後も系外へと排出された頭数 は少なかった。一方、死んだ線虫を接種した場 合、黑ボク土を除いて1.0 PV 程度の浸透で多くの Miが系外へと排出された。ここから、生きた線 虫は非常に早い水流に対して強い抵抗性を示す ことが判明した。ガラスビーズや砂に比べて黑
ボク土は狭窄部を含む複䧱な間隙構造をとると ともに団粒構造をとるため、死んだ線虫であっ てもカラム内部の土壌に捕捉され、系外へと排 出が非常に小さかったものと考えられる。土壌 構造の違いや間隙構造の違いがMiの移動に大き な影響を与えることが明らかとなった。

原田祐樹 ·吉賀豊司・近藤榮造 (佐賀大農) A phelenchus avenaeの土壤生残性に対する土壤細 菌の影響 Y. Harada, T. Y oshiga and E. Kondo (Saga Univ.) Influence of soil bacteria on survival of A phelenchus avenae in soil

土壤生態系における線虫と微生物の関係は密 接である。これまで、細菌食性線虫と細菌また は菌食性線虫と菌類との関係については多くの 報告があるが、菌食性線虫と土壤細菌間の相互 作用には不明な点が多い。本研究では特に土壤 細菌の線虫密度抑制効果について検討するため、 菌食性線虫 A phelenchus avenae (以下、線虫) と土猿細菌 Bacillus subtilis (以下、細菌) を用 い、マイクロコズム実験を試みた。滅菌および 非滅菌の有機栽培圃場土が10 g入った $50 \mathrm{ml}$ 遠心 管に500頭の線虫を加え、経時的に二層遠心浮遊 法を用いて線虫を回収したところ、滅菌区に比 べ非滅菌区では 3 日後から 5 日後に急激な線虫 数の低下がみられた。同樣に、滅菌有機栽培圑 場土に線虫 (500頭) と細菌（1×108細胞）また は線虫のみを加えて線虫の生残性を調査したと ころ、線虫と細菌の入った区では線虫のみの区 に比べて線虫の生残性が低下した。また、LB液 体培地を用いて培養した細菌中に無菌化した線 虫を加えたところ、線虫の生存率に大きな変化 は見られなかった。以上の結果からB. subtilisに A . avenaeの密度を抑制する効果があることが示 唆された。

浅川満彦 (酪農大・獣・感染/病理, 野生動物医 学センター) 外来種の存在で野生鳥獣と線虫の 宿主-寄生体関係が複雑化している M. A sakawa (Dep. Pathobiol., Sch. Vet. Med. \& Wild A nimal Medical Center) The host-parasite relationships between alien terrestrial vertebrates and their para- 
sitic helminths in Japan

本学会第11回大会で日本産野生鳥獣から記録 された寄生線虫類の概要について紹介した(浅 川・長谷川，2003で公表)。弚のうち、自然界あ るいは关れに近い環境で飼育されている鳥獣に 見られる宿主 - 寄生体関係は、外来宿主 - 外来 線虫、在来宿主 - 外来線虫、外来宿主 - 在来線 虫、在来宿主 - 在来線虫の 4 つの組合せに収斂 された。外来種介在という視座でこの類型を眺 めると、前 3つの宿主 - 寄生体関係が問題とな る。光こで、それぞれの類型ごとにヒト、動物 および自然生態系に与える可能性のある悪影響 などについて論考した (浅川, 2005，2008)。寄生 線虫相における「外来種問題」とは、単に外来 蠕虫の存否に論点を集中させるのではなく、外 来性の宿主あるいは線虫が介在することにより 生じた複杂倠な宿主 - 寄生体関係を認識し、光れ ぞれについて研究を遂行することが確認された。 このとりまとめは、文科省科学研究費 (N 0.18510205) およひ環境省平成19年度地球環境 研究総合推進費 (F-062) の助成を受けた。

参考文献: 浅川満彦. 2005. 保全生態学研究, 10: 173-183. 浅川満彦. 2008. 外来種介在により複杂隹化 する日本列島産野生哺乳類と蠕虫の宿主-寄生体 関係: 現状と今後. 生態学・疫学談話会ニュー ス(21): 4-14. 浅川満彦・長谷川英男. 2003 . 日本 で記録された鳥類と哺乳類の寄生線虫類. 日本生 物地理学会報, $58: 79-93$.

平林公男 - 西川健一 - 坂井規浩 - 宮原裕一 - 花 里孝幸 (信州大) ・福原晴夫 (新潟大) 自然 湖沼沖帯における水生線虫類の長期変動 $K$. Hirabayasi, K. Nishikawa, N. Sakai, Y. Miyabara, T. Hanazato (Shinshu Univ.) and H. Fukuhara (Niigata Univ.) Distribution and seasonal changes of aquatic nematodes in a shallow lake

諏訪湖湖底に生息する自由生活線虫類の個体 群動態を明らかにするために、2003年より湖心 (6 m) において10日に1回の調査を行った。ま た、1980年代と近年との個体数密度の比較も行 つた。線虫類の個体数密度の年変動は2003年か ら2005年にかけて有意に減少し $(P<0.05) 、 2006$
年には有意に増加した $(P<0.05)$ 。各年におけ る季節変化は2005年の春期を除き、1 年を通し て有意な季節変動は認められなかった。水深 5 m以深の地点において、1980年と現在とで比較し てみると、1980年10月には168,711〜238,133匹 $/ \mathrm{m}^{2}$ であったものが、2006年8月では23,422匹/m²

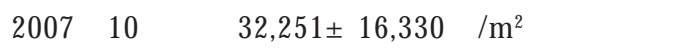
り、減少傾向にあることが示唆された。近年、 線虫類が減少している理由として、底泥直上水 中の溶存酸素量、泥温、底泥有機物含量や光の 質的変化など、樣々な要因が考えられるが、現 状では光の特定には至っていない。

奥村悦子 · 田中龍星 - 吉賀豊司 - 近藤榮造 (佐 賀大農) Caenorhabditis japonica耐久型幼虫がべ ニツチカメムシから離脱する要因 E. Okumura, R. T anaka, T. Y oshiga and E. Kondo (Saga Univ.) Cues for Caenorhabditis japonica dauer juveniles to leave their host bug, Parastrachia japonensis

Ceanorhabditis japonicaはベニツチカメムシに随 伴した生活史をもつ。ベニツチカメムシ雌成虫 体表面に付着しているC. japonica耐久型幼虫はカ メムシが産卵・子育てに入ると静止状態から運 動性を回復し、カメムシから離脱後カメムシの 巣周辺で増殖し、次世代のベニツチカメムシに 随伴することが明らかになってきた。しかし、 カメムシから D漓隹脱する要因は未だ明らかに なっていない。乥こで本研究では離脱要因を解 明する手がかりを得るため、抱卵・子育て個体 と休眠個体間でのDJの離脱樣相ならびにDJの誘 引・定着力の比較を行った。湿度を高く保った プラスチックカップに休眠個体を1頭入れて、 カップ内に降りてきた線虫を経時的に計数した ところ、カメムシから離脱する線虫数は少なく、 10日目以降でもかなりの線虫がカメムシに残っ ていた。また、飭となる大腸菌のついた培地を カップの中に入れた場合にも同樣の結果だった。 野外採集した抱卵雌成虫を用いた場合、1 週間 以内に多くの線虫がカメムシから離脱し、幼虫 孵化前でも線虫がいなくなる個体もみられた。 一方、抱卵 - 子育て個体と休眠個体間でD」対 する誘引・定着力には大きな違いは見られなか 
つた。以上のことから離脱要因は雌成虫の有す る誘引・定着性の変化ではなく卵塊またはカメ ムシ巣内に存在する他のcueが関与することが示 唆された。

田中龍聖 · 奥村悦子・吉賀豊司 ·近藤栄造 (佐 賀大農）＼cjkstart非休止状Caenorhabditis japonica耐久型 幼虫の生存期間が短い原因は貯蔵脂質の消耗に よるためか? R. Tanaka, E. Okumura T. Y oshiga and $E$. Kondo (Saga Univ.) Is low survivability of non-quiescent Caenorhabditis japonica dauer juveniles due to consumption of storage lipid?

Caenorhabditis japonicaはベニツチカメムシ (以 下カメムシ) に随伴する細菌食性線虫である。 増殖によって新たに産生された耐久型幼虫 (DJ) は非常に高い運動性を示し、宿主カメムシの探 索を行う。これまでの研究においてDJはカメム シ体表面に付着することによりDJの休止状態が 誘導され、代謝の低下によってエネルギー消費 が抑制されるとともに、乾燥および微生物の感 染から保護されることによって、長期生存する ことが示唆された。一方、カメムシ非随伴時の DJは、生存期間が約15日程度と短い。これはC． japonica DJは他種のDJと比へてて運動性が非常に高 く、エネルギー消費が激しいためだと考えられ る。本研究ではエネルギー源の一つとして貯蔵 脂質であるトリアシルグリセロール (TG) に注 目し、C. japonica DJにおけるTGの脂肪酸組成お よび量的な変化を示すとともに生存期間と $T G$ 量 との関係について考察する。

小坂 肇・佐山勝彦 (森林総研北海道) ・神崎 菜摘 (森林総研) - 高橋純一 (京大生態研) 牧野俊一 (森林総研) 北海道産在来種マルハ ナバチから検出されたタマセンチュウ H Kosaka, K. Sayama (FFPRI Hokkaido), N. Kanzaki (FFPRI), J. T akahashi (Kyoto Univ.) and S. Makino (FFPRI) Sphaerularia sp. isolated from native Bombus spp. in Hokkaido

Sphaerularia (タマセンチュウ) 属の線虫には、 ヨーロッパで記載されマルハナバチを主な宿主 とするS. bombi (マルハナバチタマセンチュウ)
と近年北海道産キイロスズメバチから検出され て新種記載されたS. vespae (スズメバチタマセン チュウ) が存在する。スズメバチタマセンチュ ウの分布を確認している森林総合研究所北海道 支所構内と光の周辺で在来種のエゾオオマルハ ナバチとエゾコマルハナバチの女王を2007年に 採集し、寄生線虫を調査した。採集した 2 種の マルハナバチにタマセンチュウ属の線虫の寄生 を初めて確認した。線虫の寄生率は、エゾオ才 マルハナバチで1％、エゾコマルハナバチで $16 \%$ であった。線虫の寄生を受けたマルハナバ チ女王の卵巣は発達しておらず、寄生により不 妊化されたと思われた。マルハナバチ体内の線 虫幼虫を観察すると、スズメバチタマセンチュ ウで見られる尾端のくびれはなかった。スズメ バチタマセンチュウを含めてリボソームLSU (D2/D3) 遺伝子の塩基配列を調べたところ、マ ルハナバチから検出された線虫同士は相同性が 非常に高く、スズメバチタマセンチュウとは多 少の変異があった。これらから、マルハナバチ から検出されたタマセンチュウ属の線虫は、ス ズメバチタマセンチュウと同所的に存在するも のの別種の可能性が高いことが明らかになった。 現在、この線虫の種への同定を進めている。

神崎菜摘（フロリダ大学・森林総研）・前原紀 敏・相川拓也（森林総研東北）・Robin M. GiblinDavis・Barbara J. Center (フロリダ大学) タラ ノザイセンチュウの「昆虫寄生態成虫」N， Kanzaki (Univ. Florida, FFPRI), N. M aehara, T. A ikawa (FFPRI-T ohoku), R.M. Giblin-Davis and B. J. Center (Univ. Florida) A n“ entomoparasitic adult form" of Bursaphelenchus luxuriosae

$A n$ " entomoparasitic adult form" of Bursaphelenchus luxuriosae was found in the tracheal system and body cavity of its carrier host, A calolepta luxuriosa (Cerambycidae). Because of its characteristic morphology, the nematode was considered to be an aphelenchoid insect parasite. However, the SSU barcode of the" parasitic form" was identical to a cultured population of B. luxuriosae. Similar to the phoretic dauer juveniles, the " parasitic form" has a 
dome-shaped head without a clearly separated lip region and degenerate digestive organs, i.e., stylet, metacorpus and pharyngo-intestinal valve. The“ parasitic form" also has several similarities to mycophagous adults; a typical set of seven caudal papillae and clearly defined cucullus on the spicules of males and a long vulval flap, postuterine sac, and similar arrangement of the reproductive system of females. Besides these characters, the parasitic form" exhibits several apomorphic attributes, e.g., four vacuole-like dots (assumed to be a sensory organ) at its lip region, elongated and thin spicule (lamina / calomus complex) of males and conical tail of females. Molecular phylogeny was used to infer that Bursaphelenchus luxuriosae is basal to the "xylophilus" group and adult insect parasitism is presumed to be an autapomorphy. This is the first confirmed report of an entomoparasitic adult form in the genus Bursaphelenchus.

魚 鎮宇·水久保隆之・乙部和紀 (中央農研) 捕食性線虫の捕食行動と殺傷能力 J. E O , T. Mizukubo and K. Otobe (Nat. A gr. Res. Ctr.) Feeding behavior and killing ability of predacious nematodes

線虫を捕食するDorylaimida目、Mononchida目、 Diplogasterida目線虫は植物寄生線虫の防除およ び土壌生態系の理解に重要である。本研究では、 微細孔隙構造を持つ基板（ $5 \times 5 \mathrm{~mm})$ 上にサツ マイモネコブ線虫100碩を放し、关れ攵れの捕食 性線虫 $(600-1,400 \mu \mathrm{m})$ が捕食する頭数と捕食樣 式を観察した。A porcelaimus sp. (口針吸引型) は1 時間当たり2.3頭を殺し、獲物の内容物を吸 収する時間は1頭あたり約18分かかった。 Mylonchulus brachyuris (咀嚼型) は2.2頭を殺し、 部分的な捸食にとどめる場合が多かった。 Miconchus sp. (吞食型) は1.9頭殺したが、体長 $900 \mu \mathrm{m}$ 以下の個体による殺傷は見られなかった。 一方、Pristionchus pacificusはサツマイモネコブ線 虫を捕食しなかったが、Caenorhabditis elegans幼 虫 (L2〜L3) を同条件で2.2頭を捕食したことか ら、獲物に選択性があることが示唆された。以 上の結果は、捕食性線虫を用いた植物寄生線虫
防除法を考慮する際の、捕食性線虫の種類と捕 食特性による防除効果予測に利用可能と考えら れる。

荒城雅昭（農環研）固場における出現頻度の 低い線虫の出現パターンと炎の消息に関する一 考察. M. A raki (Nat. Inst. A gro-environ. Sci.) Rare nematodes in a field; where are they from?

夏作に陸稲を連作している茨城大農場のマイ クロプロットで、オカボシストセンチュウが 2 連作後の2005年春の調査で初めて検出され、光 の後被害が発生するに至ったことを報告した。 不耕起区を含むこのマイクロプロットでは、農 環研不耕起堆肥連用固場を特徵付けるA croberes、 Wilsonema、Bastianiaといった属の線虫は密度が 極めて低く、Bastiania属は当初検出されなかっ た。本属の初検出は2004年春の調査で、以降は わずかながら継続して検出されている。本属や オカボシストセンチュウは昆虫との関連も考え にくいので、茨城大農場にもともと低密度で生 息していたものであろう。一方、不耕起堆肥連 用固場に隣接する慣行栽培圃場では、Wilsonema 属は2002年秋以降検出されるようになったが、 A croberes属、Bastiania属などは未検出である。 農環研の他固場の例では、過去に見られたラセ ンセンチュウやオオハリセンチュウなどが検出 されなくなったこともある。固場に線虫が存在 しないことを示すことは難しいが、Bastiania属 はこの慣行栽培戋場には生息していないのでは なかろうか W ilsonema属やBastiania属の線虫が 生息しない圑場では、これらの線虫が増えるよ うな条件が与えられても検出されるようになる ことはない。線虫を圑場の状態などを示す標徵 として利用する際にはこの点に留意する必要が あろうロ

岡田浩明 - 丹羽 慈 - 竹本周平 (農環研) - 小 松崎将一 (茨城大) 水田と畑とで線虫群集はど う異なるか? H. Okada, S. Niwa, S. Takemoto (Nat. Inst. A gro-Env. Sci.) and M. Komatsuzaki (Ibaraki Univ.) What are the differences in nematode community structure between paddy field and upland crop 
field?

水田は野生生物の生息地や温暖化ガスの発生 地として生態学的、生物地球化学的に重要であ る。線虫も生息するが、畑や森林などの陸域に 比べ群集レベルでの調査例は非常に少ない。本 研究では、隣接の陸域環境（陸稲またはダイズ 畑、以下UF) と比較することで水田 (PF) の線 虫群集の特徵を明らかにしようとした。2007年 より入水前、湛水期、落水期に土猿を採り分析 している。湛水期の水田土壌は酸素が少ないた め、物理的覞乱を評価するM aturity Index と Structure Index、有機物分解の遅速を評価する Enrichment Index、系状菌と細菌との比を評価す るChannel Indexの值はいずれもPF <UFとなると 予想した。しかし実際には、必ずしも予想通り ではなかった。これは、湛水期の水田独特の線 虫種が出現したためと考えられた。また落水期 には、酸化的環境への移行により有機物が急速 に分解され、弚れに反応したcp1の細菌食性線虫 (Rhabditidae科) が急増するなど、群集構造が大 きく変化した。さらに、上層 $(0-15 \mathrm{~mm})$ と下層 (15-50 mm) との間でも線虫の密度や群集構造が 異なることが判明した。

竹本周平 (農環研) - 大場広輔 (畜草研) - 岡 田浩明 (農環研) 反応速度論に基づく線虫群 集定量手法の検討 S. T akemoto (Nat. A gro-Env. Sci.), H. Oba (Nat. Liv. Gras. Sci.) and H. Okada (Nat. A gro-Env. Sci.) A kinetic approach for quantification of nematode community

近年、分子生物学的手法のひとつであるPCRDGGE法が線虫群集分析に利用されている。 DGGE法では、バンドパターンと光の輝度が本来 の群集組成の差異を反映しており、これに基づ きサンプル中の多種線虫のアバンダンスを一度 に評価できることが利点である。しかし、PCR の増幅効率が種ごとに異なる場合、定量結果に バイアスを生じるお光れか指摘されている。光 こで、PCRの反応速度論に基づくモデルを考案 し、反応条件等に影響されにくい定量手法につ いて以下のとおり検討した。Acrobeloides sp.（以 下、Acro） からのPCR 産物 $0.4 \times 10^{-6} \mathrm{ng} / \mathrm{ml}$ を内部
標準として添加し、プライマー濃度を0.288から $0.096 \mu \mathrm{M}$ の 5 段階に変化させた一群の反応系を用 い、Tylencholaimus parvus (以下、Tyl) からの PCR 産物 $0.4 \times 10^{-6} \mathrm{ng} / \mathrm{ml}$ を鋳型DNA としてPCR DGGEによる定量を試みた。Tylのバンドの輝度 は、内部標準であるA croの关れに対して、両対 数をとると直線回帰できた。このことは、モデ ルからの予測とよく一致していた。また、Acro に対するTylのDNA 量比の推定値は平均5.2 ( $\mathrm{n}=$ $5, \mathrm{CV}=113.1 \%$ ) となり、ばらつきは大きいもの のオーダーとしては真の值とおおむね一致した ので、本法は将来的に有望と思われた。今後は、 ばらつきを小さくする実験条件を検討するとと もに、サイクル数等PCR 条件の変化に対して本 法が頑健であるか否かを確認する必要がある。

丹羽 慈 · 岡田浩明 (農環研) - 坂本一憲 · (千葉大) ·金子信博 (横浜国大) 落葉広葉樹林 における土壤線虫群集構造の季節変動 S. Niwa, H. Okada (Nat. Inst. A gro-Env. Sci.), K. Sakamoto (Chiba Univ.) and N. Kaneko (Yokohama Nat. Univ.) Seasonal dynamics of soil nematode community structure in a deciduous broad-leaved forest

線虫は森林土壤中に高密度に生息し、光の群 集構造は土壤の養分無機化機能と密接に関連し ていると考えられている。しかし、森林土鋊に 生息する線虫の群集構造が、季節に伴ってどの ように変動しているのかを調査した例は少ない。 弚こで、茨城県北部の落葉広葉樹林において、 1 年間を通じて土壃線虫群集 (科レベル) の調 査を行った。線虫総個体数は、秋に最大となり、 冬〜春に漸減して、夏に最低となった。食性群 別にみると、細菌食性線虫と系状菌食性線虫が ともに総個体数と同樣の季節変動を示した。前 者では冬の個体数減少は有意でなく、春に大き く減少したのに対し、後者では秋〜冬にかけて の減少が大きく、冬〜夏の変動は小さかった。 系状菌食者の変動は、系状菌バイオマスの変動 と対応していた。捕食性線虫の個体数は、1〜 2 か月前の細菌食性線虫の個体数と高い相関を 示し、細菌食性線虫を主な餌資源としているこ とが示唆された。生活史形質に基づいた機能群 
分けを行うと、比較的増殖の速いグループ ( $c p$ 值 2 ) で有意な季節変動が認められた。主成分 分析による座標付けにより、線虫の群集構造が
春と夏で大きく異なることが示された。秋と冬 の群集も互いに区別され、いずれも春と夏の群 集の中間的な構成であった。 